\title{
Treefall gap characteristics within an Appalachian hardwood forest in West Virginia: Influences of topographic position and forest type
}

Jamie Marie Himes

West Virginia University

Follow this and additional works at: https://researchrepository.wvu.edu/etd

\section{Recommended Citation}

Himes, Jamie Marie, "Treefall gap characteristics within an Appalachian hardwood forest in West Virginia: Influences of topographic position and forest type" (2009). Graduate Theses, Dissertations, and Problem Reports. 2907.

https://researchrepository.wvu.edu/etd/2907

This Thesis is protected by copyright and/or related rights. It has been brought to you by the The Research Repository @ WVU with permission from the rights-holder(s). You are free to use this Thesis in any way that is permitted by the copyright and related rights legislation that applies to your use. For other uses you must obtain permission from the rights-holder(s) directly, unless additional rights are indicated by a Creative Commons license in the record and/ or on the work itself. This Thesis has been accepted for inclusion in WVU Graduate Theses, Dissertations, and Problem Reports collection by an authorized administrator of The Research Repository @ WVU. For more information, please contact researchrepository@mail.wvu.edu. 


\title{
JAMIE MARIE HIMES
}

\author{
Thesis submitted to the Davis College of Agriculture, Forestry, \\ and Consumer Sciences at West Virginia University \\ in partial fulfillment of the requirements \\ for the degree of \\ Master of Science \\ in \\ Forestry
}

\author{
Approved by \\ Eric Heitzman, Ph.D., Committee Chair \\ James Rentch, Ph.D. \\ Michael Strager, Ph.D. \\ Gary Miller, Ph.D.
}

Division of Forestry and Natural Resources

Morgantown, West Virginia

2009

Keywords: Appalachian Hardwoods, Disturbance, Stand Dynamics, Topography, Tree-fall Gap Dynamics, West Virginia University Research Forest 


\section{ABSTRACT \\ TREEFALL GAP CHARACTERISTICS WITHIN AN APPALACHIAN HARDWOOD FOREST IN WEST VIRGINIA: INFLUENCES OF TOPOGRAPHIC POSITION AND FOREST TYPE}

\section{JAMIE MARIE HIMES}

We examined the attributes of canopy gaps on the 3,100 ha West Virginia University Research Forest (WVURF) near Morgantown, WV. The WVURF is a $70-80$ year- old, secondgrowth, Appalachian hardwood forest. The objectives of this study were: 1) to describe specific gap characteristics (size, age, and fraction) of the forest as a whole, and 2) to assess whether gap characteristics varied by slope position (cove, mid, ridge), aspect (NE, NW, SE, SW), and forest cover type (cove hardwood, mesic oak, xeric oak).

Transect lines were digitized using GIS in ArcMap and systematically placed throughout the forest to include a range of aspects and slope positions. Sixty-one transects were established, with a total length of 22,508 m. Line intersect sampling was used to select gaps. Eighty gaps were identified. The average gap size was $98.59( \pm 134.17) \mathrm{m}^{2}$. The average expanded gap size was $287.64( \pm 238.49) \mathrm{m}^{2}$. Gap age ranged from $2-29$ years old with a mean age of $16.42( \pm 6.3)$ years. Overall, $2.73( \pm 2.48) \%$ of the forest was composed of gaps. These figures are small compared to old growth forests in the region. WVURF is a young forest, therefore the gaps created are relatively small and scattered. We speculate the WVURF remains in the late stem exclusion to early understory re-initiation stage.

There were no differences in gap size by aspect or slope position. Cove hardwoods had larger gap sizes than mesic and xeric oak. Expanded gaps were also largest in cove hardwoods and on northwest and southeast aspects. There were no differences in gap age based on slope position, aspect, or forest type. Gap fraction did not differ by slope position, but gap fraction was greatest on southeast slopes and in cove hardwoods.

Regeneration within gaps included a variety of species including oaks (Quercus sp.), black cherry (Prunus serotina), black birch (Betula lenta), maple (Acer sp.), and understory shrubs. Oak regeneration importance values did not vary by aspect or forest type, but were significantly higher in coves and mid- slopes than on ridges. Almost two- thirds of gap-makers, trees whose death created the gap, were oaks.

Understanding the disturbance dynamics, especially the canopy gap dynamics, of second growth forests is important in the development of ecosystem management policies. The framework advanced by this study could aid land managers in implementing informed management policies and practices that more closely resemble the natural disturbances that are occurring in the WVURF. 


\section{ACKNOWLEDGEMENTS}

I would like to thank my parents, Janice and Thomas Himes and the rest of my family for their lifelong commitment in helping me succeed and urging me to be the best I could be. I would also like to thank by boyfriend Henry, for his support in all my endeavors. He has continuously encouraged and supported me throughout my graduate career.

To my graduate advisor, Eric Heitzman, it was an honor to work with you. Thank you for your continuous support and assistance. I could not have done any of this without you. A special thanks to my committee members, Dr. James Rentch, Dr. Michael Strager, and Dr. Gary Miller, for all their assistance and contributions to this project.

I am forever indebted to my field assistant, Aaron Tumblin, for the many long days and hours spent in the woods. He was an invaluable assistant and I could not have done the same quality of work without his help. I would also like to thank James Rentch for help with analyzing my tree core samples and Michael Strager for help with GIS. In addition, I would like to thank Kenneth Carvell for his help with history lessons and all the old pictures that were provided.

Finally, I would like to thank the West Virginia University Division of Forestry and Natural Resources for the wonderful opportunity to study with their program, the Coopers Rock State forest for permission to study their land, and The University Research Forest (Mike Boyce, and Robert Driscole) for the shapefiles and maps provided. 


\section{TABLE OF CONTENTS}

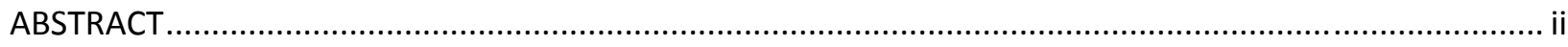

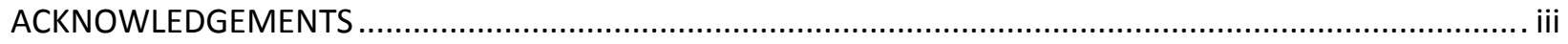

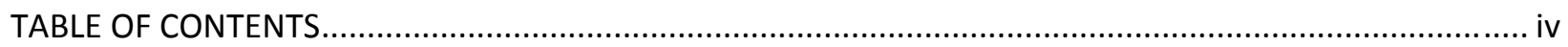

LIST OF FIGURES

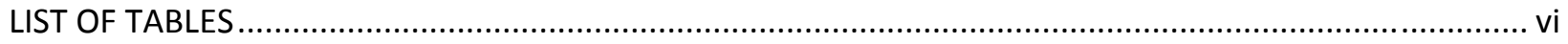

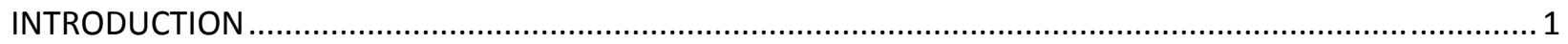

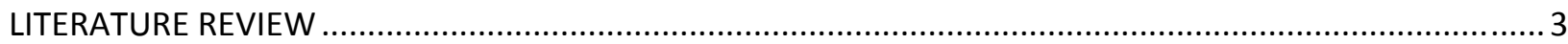

History of West Virginia University Research Forest ............................................................................. 4

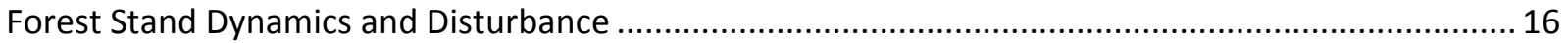

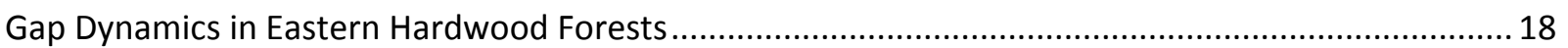

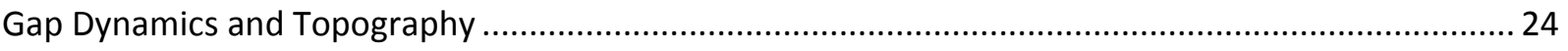

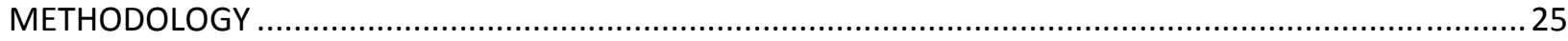

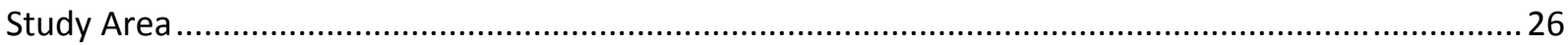

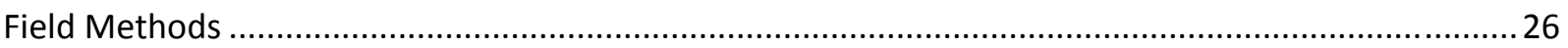

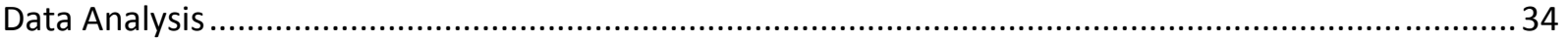

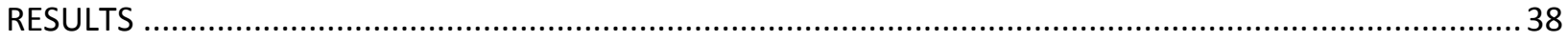

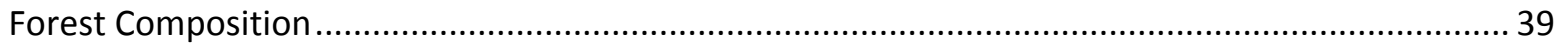

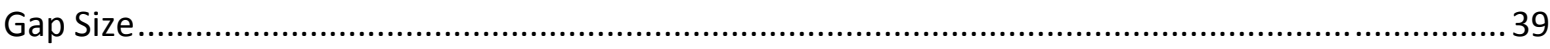

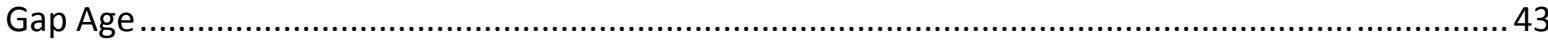

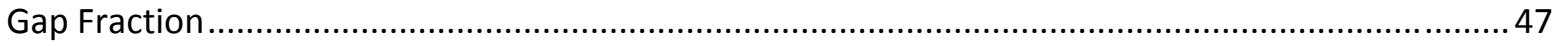

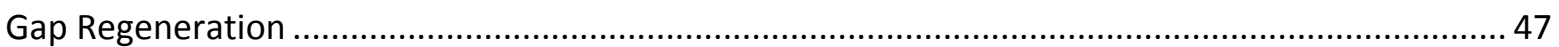

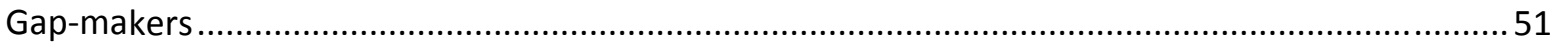

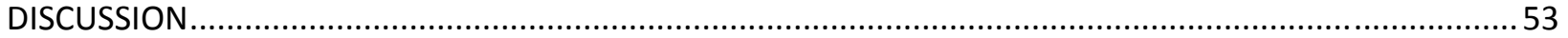

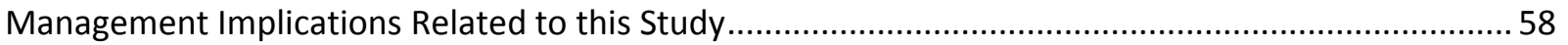

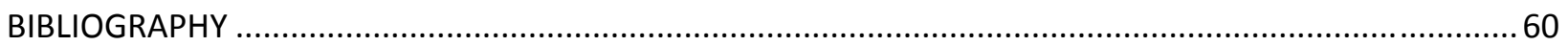

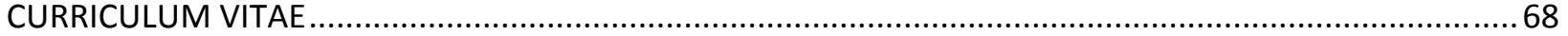




\section{LIST OF FIGURES}

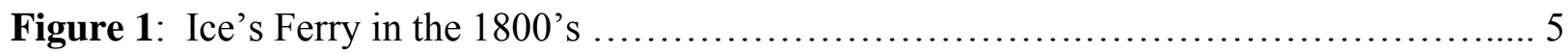

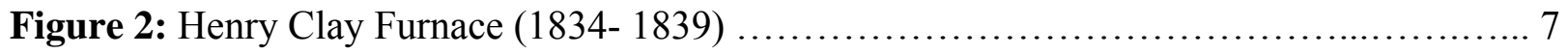

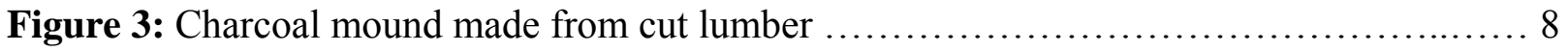

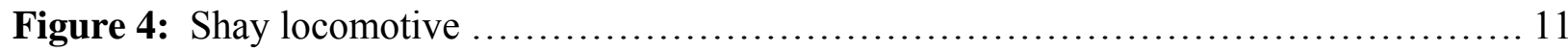

Figure 5: The remains of a lumber mill in the West Virginia University Research Forest ...... 12

Figure 6: $\mathrm{CCC}$ work done in Coopers Rock State Forest .................................. 14

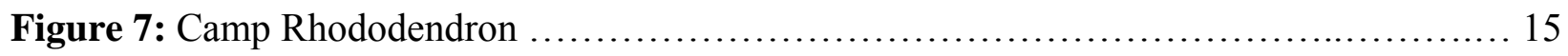

Figure 8: Location of the West Virginia University Research Forest ........................ 27

Figure 9: Transect location thoughout the West Virginia University Research Forest ........... 28

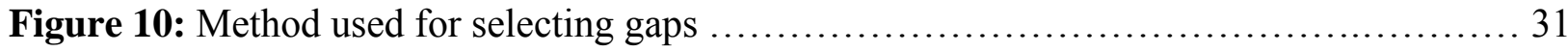

Figure 11: Canopy gap caused by the death of one or more trees .......................... 32

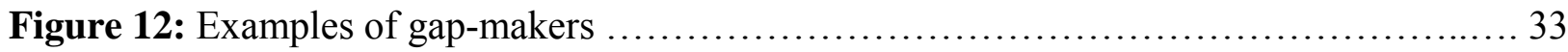

Figure 13: Distribution of gap size classes on the West Virginia University Research Forest

Figure 14: Gap age distribution of gap age classes on the West Virginia University Research

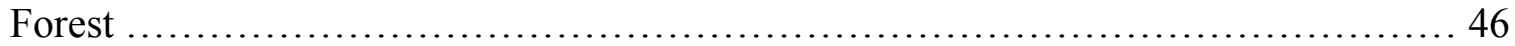

Figure 15: Species importance values for regeneration within gaps on the West Virginia

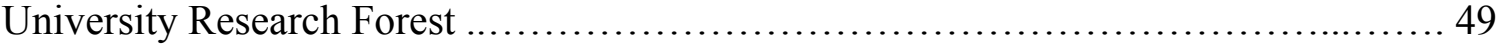

Figure 16: Species composition of gap-makers on the West Virginia University Research Forest 


\section{LIST OF TABLES}

Table 1: Studies of gap dynamics in mixed mesophytic forests on the West Virginia University

Research Forest

Table 2: Species importance values by forest type on the West Virginia University Research

Forest

Table 3: Gap size $\left(\mathrm{m}^{2}\right)$ characteristics varying by aspect, slope position, and forest type on the West Virginia University Research Forest

Table 4: Expanded gap size $\left(\mathrm{m}^{2}\right)$ varying by aspect, slope position, and forest type on the West Virginia University Research Forest

Table 5: Gap age (years) by aspect, slope position, and forest type on the West Virginia University Research Forest

Table 6: Gap fraction (\%) by aspect, slope position, and forest type on the West Virginia University Research Forest

Table 7: Oak regeneration importance values by aspect, slope position, and forest type on the West Virginia University Research Forest 


\section{INTRODUCTION}

The dynamic nature of a forest ecosystem, its past, present, and future, has been an important area of research for many silviculturists (Runkle 1992). Natural disturbances are a source of environmental heterogeneity and patch effects, which occur on a wide variety of spatial and temporal scales (Valverde and Silvertown 1997, Clinton and Baker 2000). Ecologists are placing increasing emphasis on the role of disturbance as an organizing factor in natural ecosystems and structuring communities (Phillips and Shure 1990, McClure and Lee 1992).

Canopy disturbances that alter light availability (as well as climate, soils and other factors) affect species composition and structure for an area (Oliver 1980, Collins and Pickett 1982, Keller and Hix 1999, Rentch et al. 2003, Hart and Grissino-Grissino-Mayer 2009). In forests of the northeastern United States where catastrophic stand destroying disturbances are rare, stand dynamics are controlled by the creation of gaps due to single or multiple overstory tree mortality. Treefall gaps formed as a result of small scale disturbances allow for seedling recruitment and growth in forests (Almquist et al. 2000). Patterns of canopy tree mortality shape forest stand structure and dynamics through influencing forest regeneration, species composition, growth rates, density, age structure, and tree regeneration and replacement (Woods 2004, Weiskittel and Hix 2002).

The West Virginia University Research Forest has a variety of slope positions (cove, mid, ridge), aspects (NE, NW, SE, SW), and forests types (cove hardwoods, xeric oak, mesic oak). Mountain environments, where there are steep topographical and elevational gradients, support forests with perhaps the greatest potential for the gap regime to vary in space (Battles et al. 1995). The purpose of this study is to assess gap characteristics (size, age, fraction, and 
regeneration). It is hypothesized that there will be statistically significant differences in these characteristics by slope position, aspect, and forest type. 
CHAPTER 1

\section{LITERATURE REVIEW}




\section{History of West Virginia University Research Forest}

The prehistory of Monongalia County covers 16,000 years of occupation by a large number of different peoples, each group having its own distinctive artifacts and settlement patterns (Core 1974). The Indians and predecessors hunted in these forests for over twelve thousands of years with permanent settlements surrounding the Pittsburgh area. In the $18^{\text {th }}$ century white colonists were settling Virginia while in the mountains of western Virginia (now West Virginia), the Six Nations of the Iroquois were fighting the Shawnee and their allies for access to land. In 1744, England purchased the land extending from the Allegheny Mountains to the Ohio River from the Six Nations, but not from the Shawnee who also had claim to the region. The Shawnee fought for their rightful claim to the land and settlers were not completely safe until 1794, when the Indians finally surrendered their land and moved west (Wiley 1883, Moreland 1940, Deike 1978, Rodd 1994).

European settlers first came into the area of the West Virginia University Research Forest (WVURF) around 1753. One of the first settlers was Frederick Ice, who began a settlement in 1759 on the Cheat River, where Lakeview and Ice's Ferry Bridge is today (Figure 1). Between 1759-1763 settlers colonized the land, navigating along Indian trials that followed streams and ridges (Wiley 1883, Moreland 1940, Deike 1978, Rodd 1994).

Since the time of European settlement the forests have been exploited. The Industrial Revolution affected the timber industry to a remarkable degree and helped to initiate the rapid denuding of the forests (Deike 1978). The first documented major disturbance upon the forests of the WVURF started in the late 1700's and was directly related to the manufacturing of 


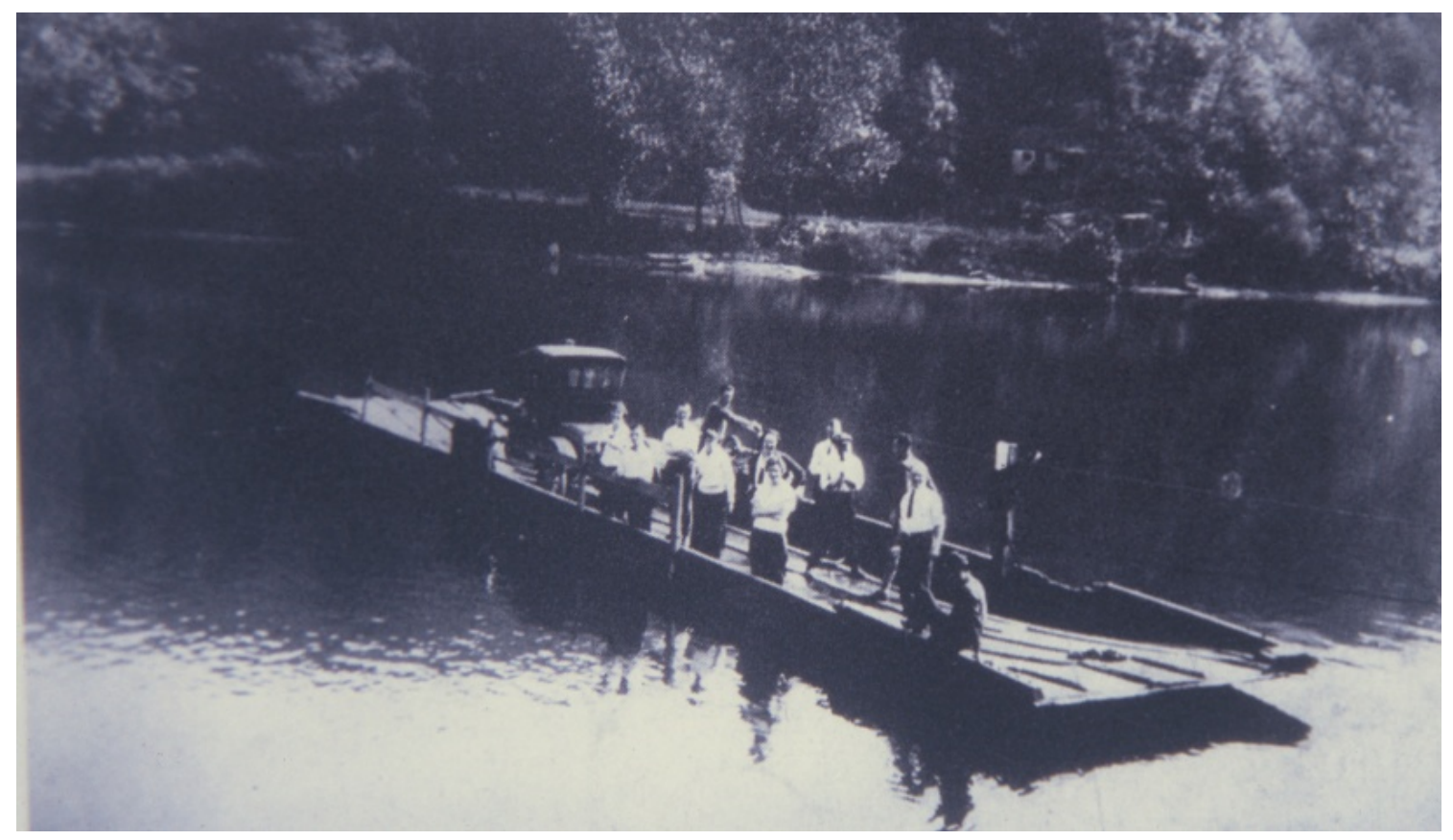

Figure 1: Ice's Ferry in the 1800's. 
whiskey. All barrels to contain the whiskey were made out of white oak. White oak was preferred because; a) white oak vessel members are plugged by tyloses which inhibit pathogen movement in inactive wood, and b) the tyloses make the wood leak resistant (Rost et al. 2006). In addition to the depletion of white oaks for the use of whiskey barrels, around 1779 charcoal production began. Four furnaces utilized the forest resources that the area had to offer. The first furnace, known as the Davis or Pleasant Furnace, was built in 1798. Wood Grove and Henry Clay (Figure 2) were both built prior to 1840 while the Anna furnace was built in 1845 (Wiley 1883, Moreland 1940, Carvell 1973, Core 1974, Rodd 1994).

Forests were cut and wood burned to produce charcoal for the iron industry. The charcoal used in the furnaces came from smoldering trees. Charcoal works better than raw wood because it can burn hotter. Wood was cut into cords $\left(3.6 \mathrm{~m}^{3}\right)$, and stacked in a circular pit about 9- $14 \mathrm{~m}$ in diameter. The wood was then arranged in a dome that was $1.5-2.5 \mathrm{~m}$ high. Most pits burned about eight cords at a time. The mound was covered with clay, leaving a single, small opening on the top of the mound, which was used to control the amount of air flow into the chamber (Figure 3). The wood would take three to ten days to smolder before it would produce charcoal and be suitable for a furnace. The main time for the wood cutting took place in the late fall, winter, and early spring. However, most of the charcoal was produced from May to October (Moreland 1940, Carvell 1973, Deike 1978, Dedek 1989, Paskoff 1989, Williams 1989, Rodd 1994). There were no recordings of wildfires following cuts; however, these heavy cuttings were almost certainly followed by fire (Carvell 1973).

The yield of charcoal varied by the quality and type of the wood. Most wood used to make charcoal was not of optimum quality. Hardwoods gave the best charcoal per cord because 


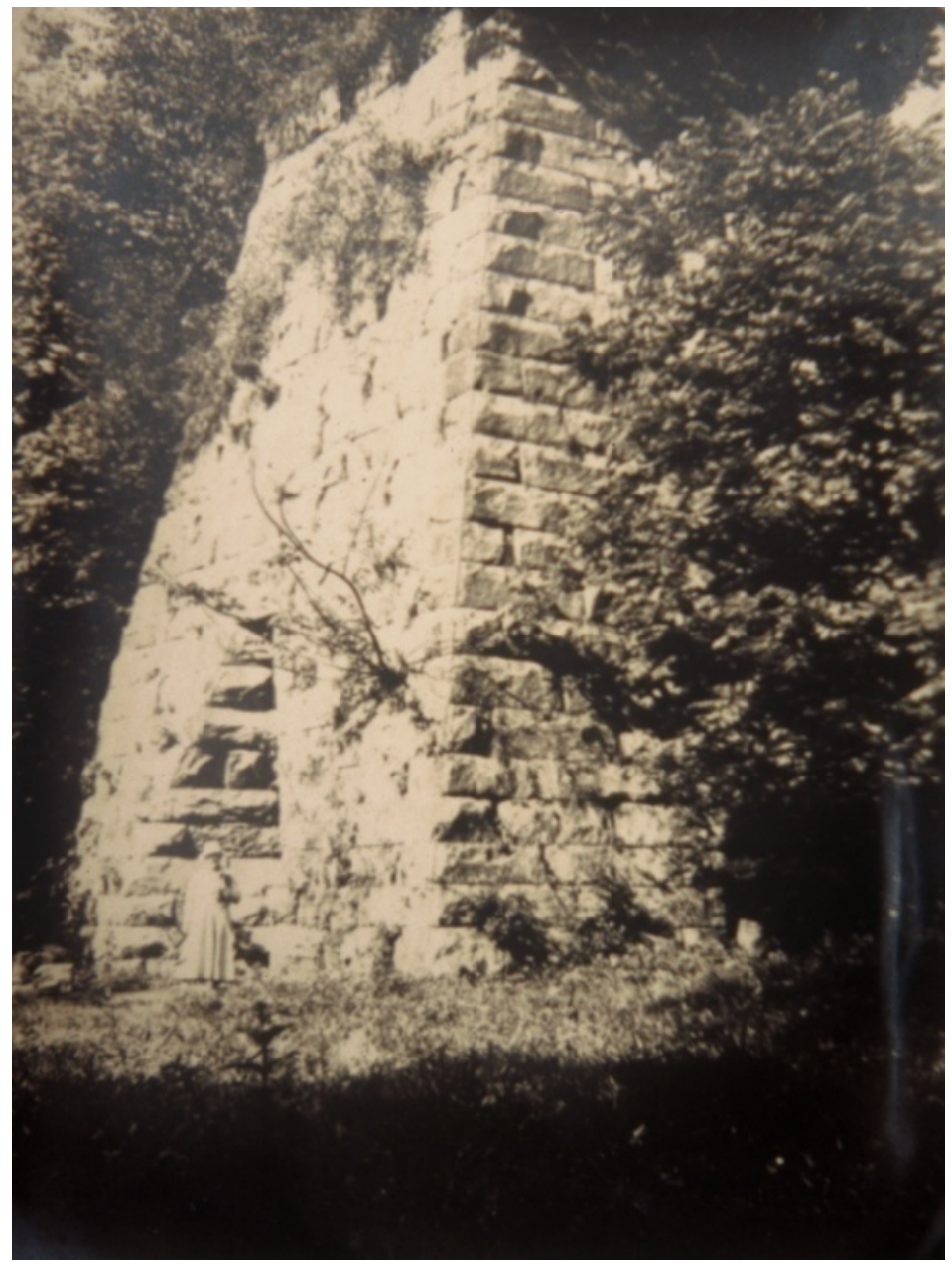

Figure 2: Henry Clay Furnace (1834- 1839) 


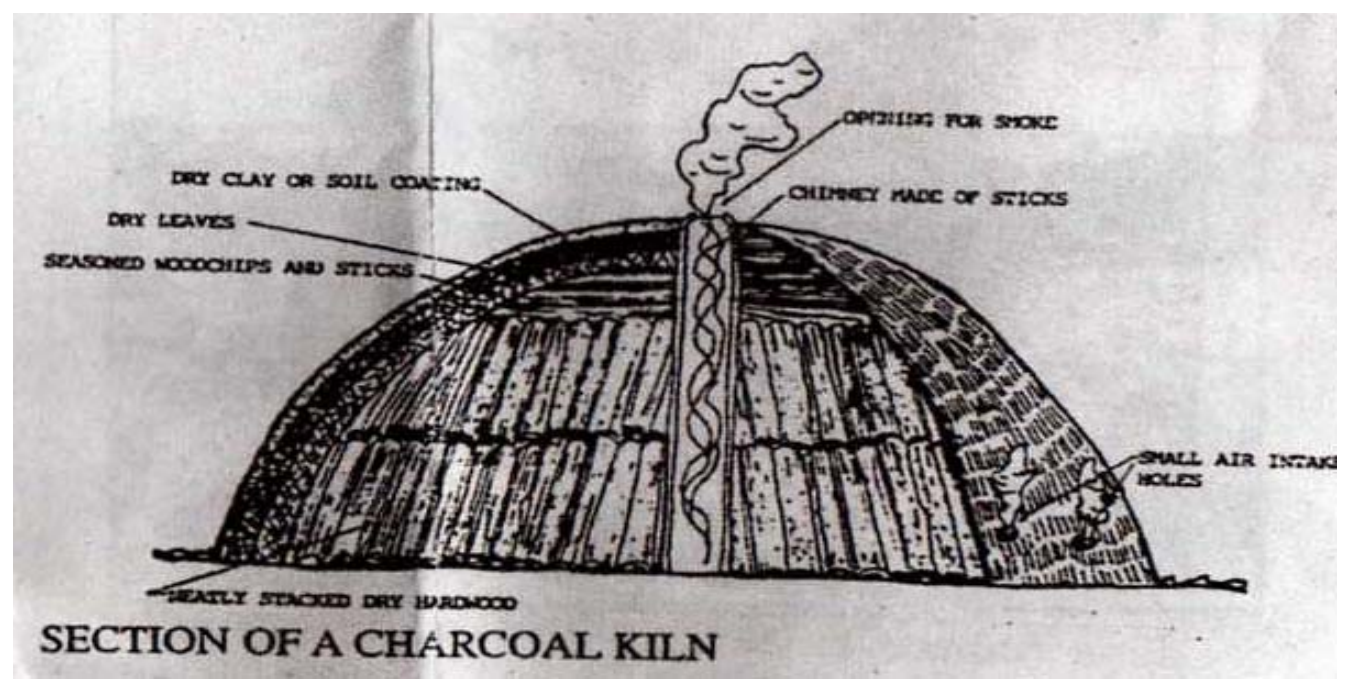

Figure 3: Charcoal mound made from cut lumber. 
they are heavy and have a tight grain and low water content. On average, a cord of wood would produce about 20-40 bushels of charcoal. On average, 61 ha of wood were cut to produce $907180 \mathrm{~kg}$ of pig iron (Williams 1989). Yearly, a charcoal furnace could consume as much as 101 ha of forest (Carvell 1973, Rodd 1994).

Iron is mined from the ground as iron ore containing the pure iron bound to other minerals (impurities). In order to obtain useable iron, the iron ore must be heated to a very high temperature, which separates the impurities from the pure iron. After processing though the charcoal furnace some iron was sold locally, but most was floated down the Cheat and Monongahela Rivers to Pittsburgh and Greensboro, Pa. The Cheat Mountain iron industry gradually declined after 1848 and suspended operations in 1868. The last of these furnaces, Anna, ceased operation in 1868 (Moreland 1940, Deike 1978, Dedek 1989, Paskoff 1989, Williams 1989, Rodd 1994). This era had many implications on the forest system and stand composition. The forests would have been cut in circles around furnaces using a coppice cut. Fires weren't recorded but seemed inevitable. At the end of the charcoal era the forests were uneven aged and in rough shape.

After the closing of the iron industry in 1868, the WVURF was purchased by the Smyth and Chess families out of Pittsburgh. During the period of 1868 - 1911 the property lay idle and the forests were slowly allowed to regenerate. The Smyth and Chess brothers sold various cutting rights to any interested person and did light selective cuttings for specific tree species to make cross ties, and shingles (Carvell 1973, Deike 1978, Rodd 1994).

In 1911 the Smyth and Chess families sold 4430 ha to the Kendall Lumber Company. At the time, a major problem and expense of the timber industry was the transportation of resources, 
particularly lumber. After trees were cut and bucked into logs of reasonable length, the logs needed to be moved to a sawmill (Deike 1978). Timber was moved out of the woods using small Shay and Climax steam engines (Figure 4). The Shay is a geared locomotive. The steam engine power is increased and its speed is produced by a gear drive. The locomotive runs on 4-wheel "trucks" like those on a railroad freight car, and it has no large driving wheels like those on ordinary locomotives. Anywhere a railroad car could go, a Shay could go, too. Sharp curves and bumpy rails posed few problems. Better yet, the wheels were small and with the gear drive the engine could climb very steep grades. The track could be built around or over almost anything, without expensive grading. Temporary tracks were laid, often following old tramways built for the iron industry. Kendall established a mill on Morgan Run in Darnell Hollow and a mill near the Henry Clay furnace (Figure 5). Small portable mills were also located throughout the forest (Carvell 1973, Deike 1978, Rodd 1994).

The Kendall Company cut extensively, leaving behind only small, scattered trees. Their band mill consumed 40,000 board feet a day. In 1929 the Summit Lumber Company leased and undertook the logging of this tract, completing the operation in the late 1930's. During this period the entire acreage of the WVURF was cut except for small areas. These locations were spared because Kendall and Summit Lumber Company went bankrupt about this time (Carvell 1973, Rodd 1994).

Wildfires followed these heavy cuttings due to the sparks from the railroad engines and heavy slash left behind. Denudated areas burned almost annually and no part of the forest escaped. Such heavy burnings left a permanent mark on the forest composition. For example, many of the oaks we see today sprouted prolifically following these fires (Carvell 1973, Rodd 1994). 


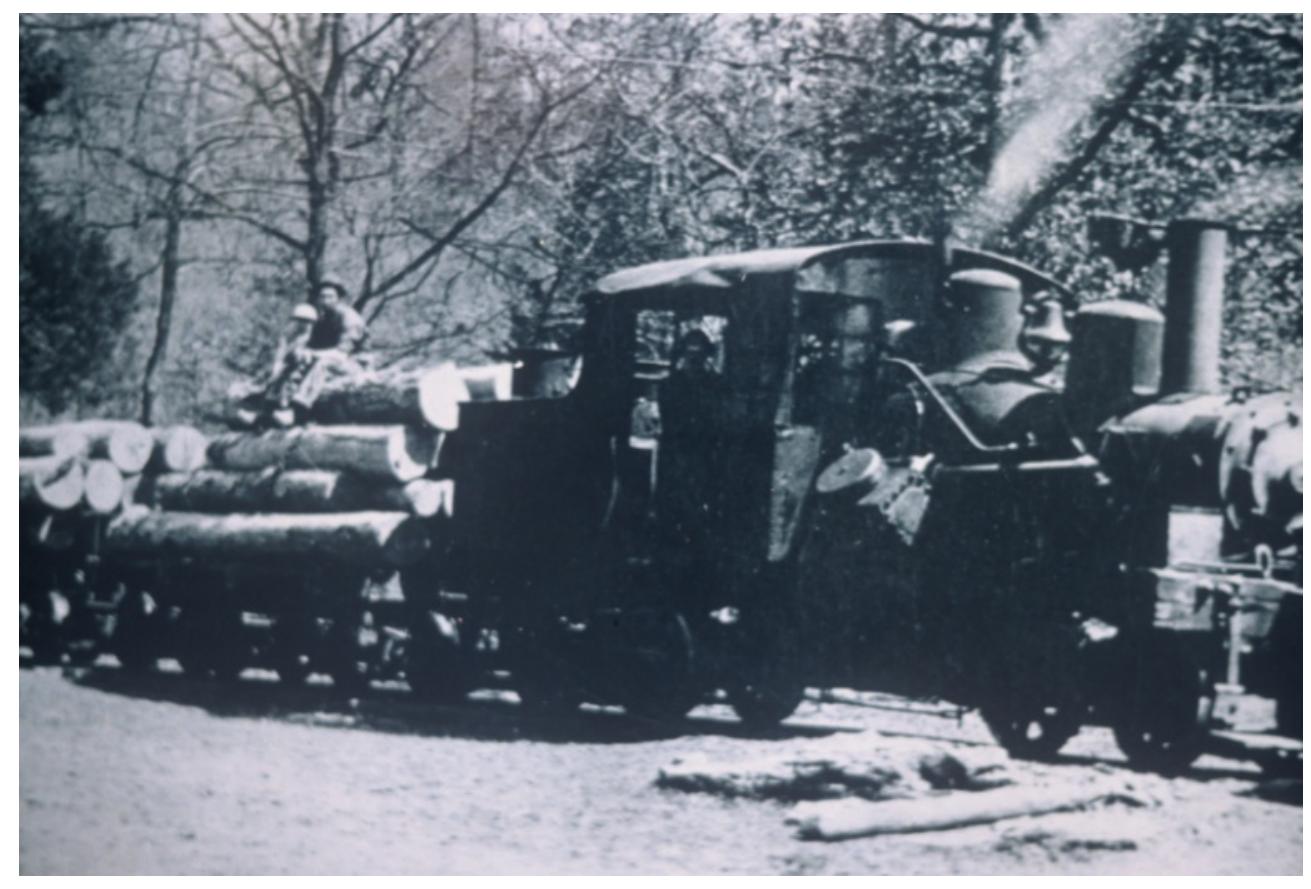

Figure 4: Shay locomotive 


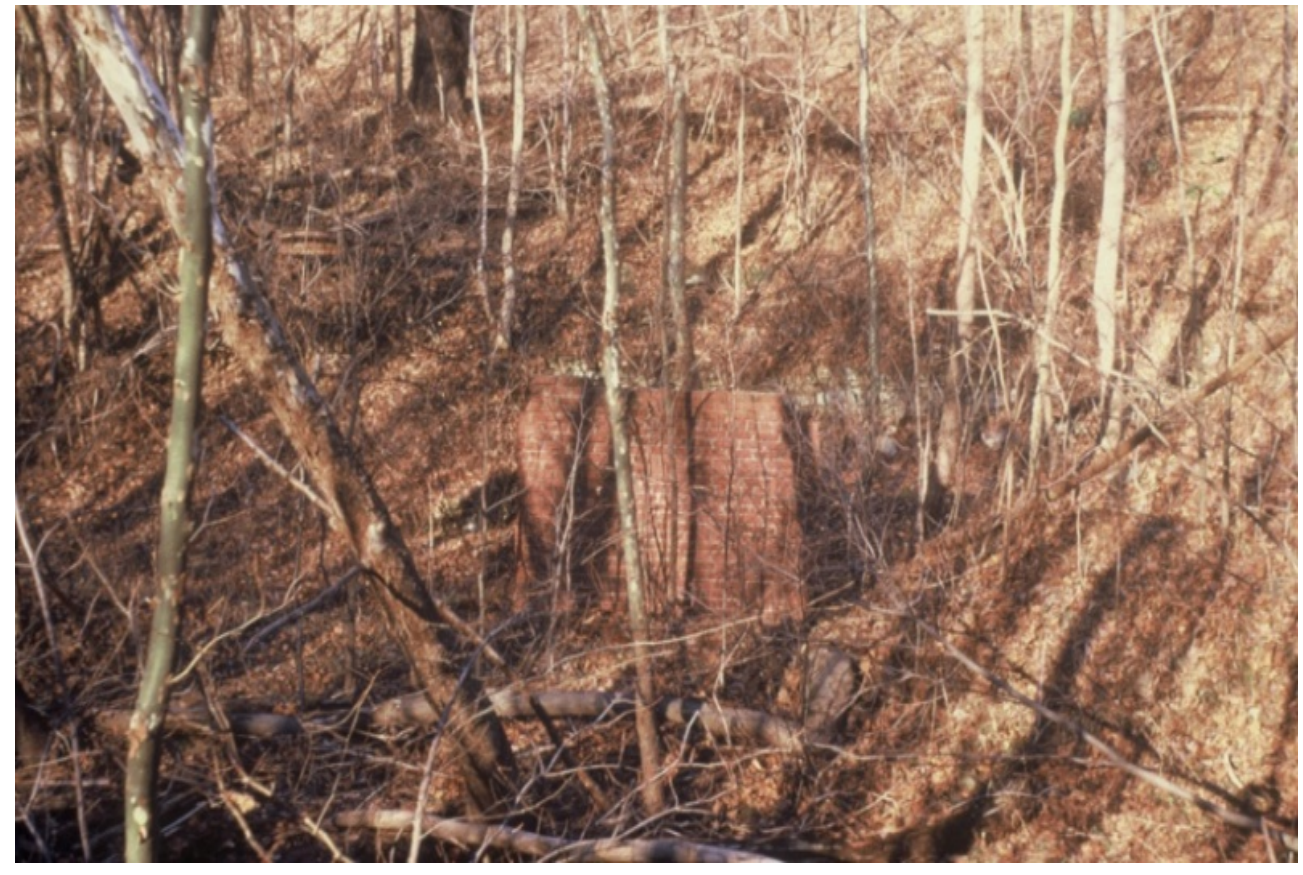

Figure 5: The remains of a lumber mill in the West Virginia University Research Forest 
Following the purchase of the WVURF by the state in 1936, the Civilian Conservation Corps (CCC) worked to improve the damaged forest and put an end to the wildfires. The land was named Coopers Rock State Forest. The CCC members were young men 18-25 who worked in a Depression-era federal jobs program doing conservation work. The army ran the camp, but every morning the men were turned over to the U.S. Forest Service. They built recreation facilities roads, thinned dense timber stands, collected tree seeds, and planted trees. Corps' men were subject to call at anytime to control forest fires on the State lands (Figure 6). The WVURF CCC was named CCC Camp Rhododendron and was located at the base of Chestnut Ridge near Fairchance Road (Figure 7). To complete its work projects, Camp Rhododendron continued to operate until the spring of 1942. By the spring most of the men had left for military service or other employment, and the camp was officially closed on March $31^{\text {st }}$ (Carvell 1973, Deike 1978, Harr 1992, Rodd 1994).

"The presence of established oaks in the overstory of a stand is often attributed to past stand disturbance” (Johnson 2002).

The abundance of oak in the present forest is closely related to past disturbances and stand histories. In northern forests heavy cutting removed the overstory and following fire understories of red and chestnut oak was released. The forest trees are even aged. White Oaks are scarce on the URF, hypothesizing that this depletion is due to the intense use of white oak for whiskey barrel making. Hemlocks are nonexistent because they are highly fire sensitive and the amounts of fire following cuttings have completely removed all hemlocks. Red Maples, Sassafras, and Blackgum are prolific sprouters and became more abundant then yellow popular following the heavy cuttings and wildfires. Red Maples, Scarlet Oaks, and Blackgum were considered trash trees, and were usually left behind during harvests, hence the reason these species are so prevalent on the WVURF. (Carvell 1973, Rodd 1994). 

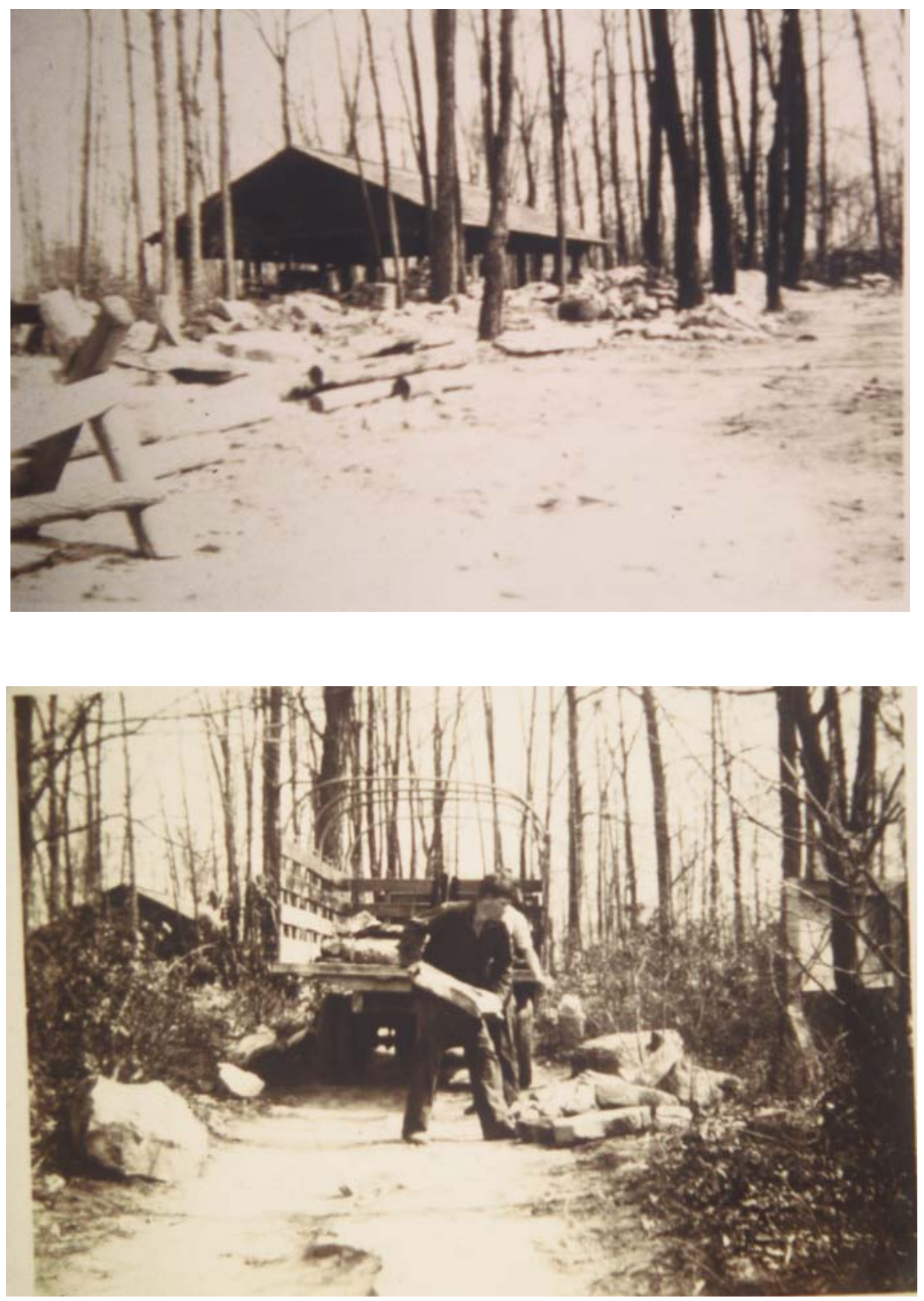

Figure 6: $\mathrm{CCC}$ work done in Coopers Rock State Forest. 


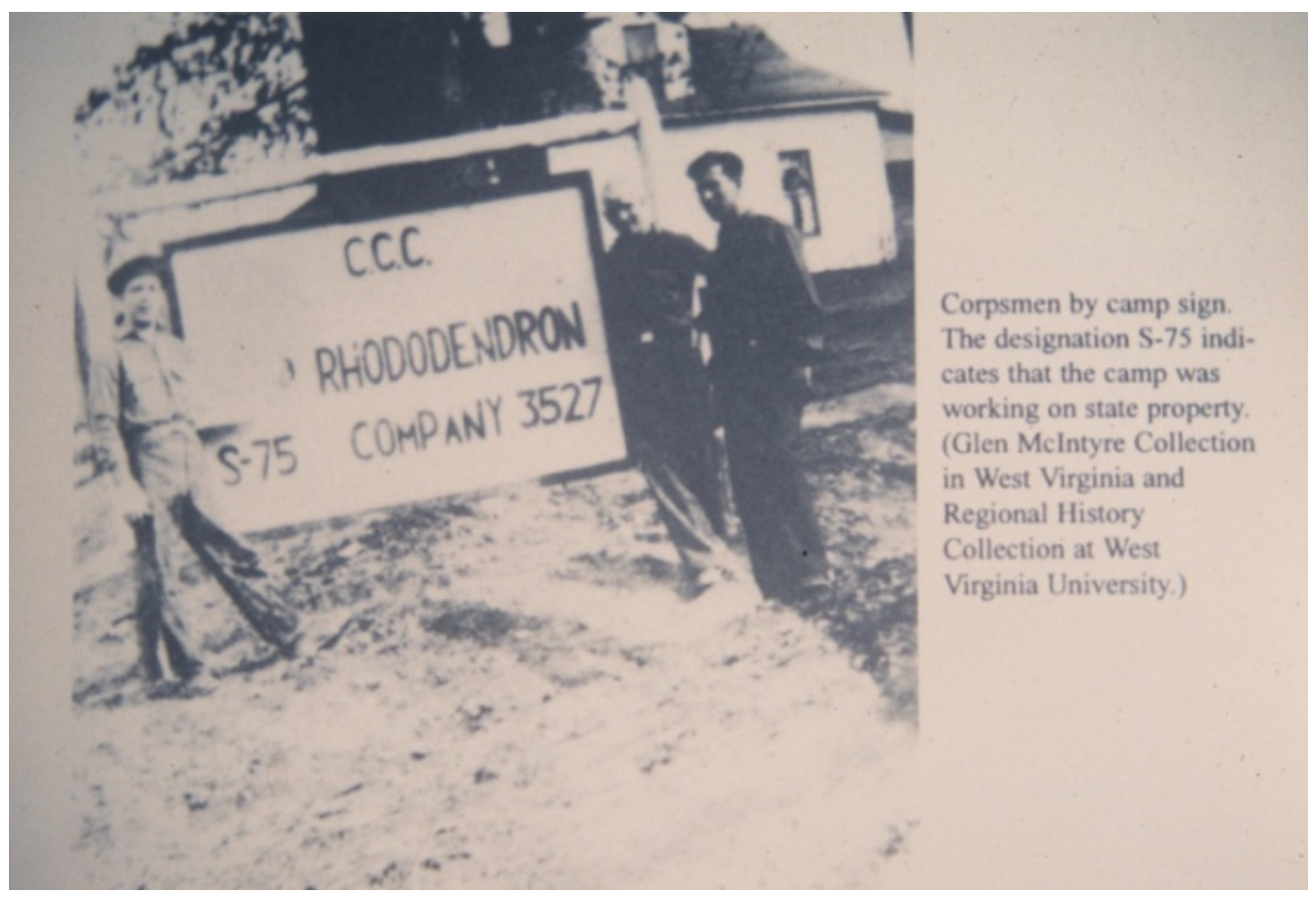

Figure 7: Camp Rhododendron 
Today, the WVURF is a 70-80 year old, even aged, mixed hardwood forest. Since the 1930s, a third of localized forest has been subjected to silviculture treatments and fire has not been reported (Carvell 1973, Rodd 1994, Fekedulegn et al. 2004, WVURF shapefiles). Several stand wide gypsy moth outbreaks occurred from 1989 to 1994 causing severe defoliation and mortality to oak species (Muzika et al. 2000).

\section{Forest Stand Dynamics and Disturbance}

The dynamic nature of a forest ecosystem, past, present, and future, has been an important area of research for ecologists and silviculturists (Runkle 1992). Forest succession and regeneration can be thought of as the sum of processes by which one canopy individual is replaced by another (Runkle 1981). The development of a forest ecosystem rarely achieves a steady state, but is interrupted by catastrophic exogenous disturbances at irregular and relatively short intervals (Bormann and Likens 1979). Natural disturbances are a source of environmental heterogeneity and patch effects, which occur on a wide variety of spatial and temporal scales (Valverde and Silvertown 1997, Clinton and Baker 2000). Ecologists are placing increasing emphasis on the role of disturbance as an organizing factor in natural ecosystems and structuring communities (Phillips and Shure 1990, McClure and Lee 1992).

The disturbance regime of a forest represents the sum total of stem and stand replacing events, and many studies have characterized individual stands and forest types by disturbance agents, severity, and return time (Oliver 1980, Collins and Pickett 1982, Keller and Hix 1999, Rentch et al. 2002, Rentch et al. 2003, Hart and Grissino-Grissino-Mayer 2009). A disturbance regime encompasses all types of disturbances (e.g., fire, windstorm, slip, avalanche) and their frequency, intensity, and spatial pattern (Ogden et al. 1991). 
As Oliver and Larson (1996) state, "Natural disturbances in forests kill vegetation and release growing space." They defined growing space as the sum of necessary resources; sunlight, water, nutrients, temperature, oxygen, and carbon-dioxide, available to the individual organisms present. Growth continues until one or more of these components becomes limited. This release of growing space, along with the type of disturbance, competition, shade tolerance, and mortality among sapling species, control the composition of the stand as a new forest canopy develops and redistributes the growing space among survivors and new individuals (Oliver 1980, Runkle 1981, Collins and Pickett 1982, Clinton 2003, Rentch et al. 2003, Gould et al. 2005). Gaps are simultaneously a source of mortality for some individuals and a source of establishment and growth for others, and the ongoing process of death and replacement has a profound effect on forest structure and composition (Rentch et al. 2002). The pattern of disturbance acts as an environmental sieve whereby species better adapted to the resulting conditions pass through the sieve and remain competitive. The less competitive species are consequently "filtered" out.

It is necessary to reaffirm the importance of small scale disturbance in forests where they are most likely to be the primary source of forest turnover. - Runkle 1981.

Natural maintenance of forest communities depends upon a dynamic balance between canopy tree death and replacement (Yetter and Runkle 1986). The pattern of these deaths (i.e., forest disturbance regime) varies for different forests from large scale, highly episodic mortality to small scale, more continuous mortality in which more trees die singly or in small groups (Yetter and Runkle 1986). Disturbances of varying size, intensity, and frequency of variously sized gaps in otherwise unbroken canopy play a major role in structuring plant communities by producing a mosaic of patches at different successional states across the landscape (Phillips and Shure 1990, Battles et al. 1995, Valverde and Silvertown 1997, Fraver and White 2005). Effects 
of these disturbances are more commonly diffuse, causing the death of scattered trees and patches rather than turnover of entire stands (Lorimer and White 2003).

\section{Gap Dynamics in Eastern Hardwood Forests}

In forests of the northeastern United States where catastrophic stand destroying disturbances are rare, stand dynamics are controlled by the creation of gaps due to single or multiple overstory tree mortality. These gaps play a critical role in maintaining canopy tree species composition, increasing the radiation, and changing the levels of soil moisture and nutrients available to regeneration (Barden 1980, Barden 1981, Runkle 1982, Yetter and Runkle 1986, Runkle 1990, Runkle 1992, Keller and Hix 1999, Forrester and Runkle 2000, Almquist et al. 2000, Clinton and Baker 2000, Busing 2005, Hart and Grissino-Mayer 2009). These events create resource heterogeneity along light, temperature, humidity, and soil resource gradients (Keller and Hix 1999, Rentch et al. 2002). In time, individual trees or groups of trees fall down creating smaller patches for younger vegetation. Eventually the whole forest will be composed of patches of varying size and age (Bormann and Likens 1979). Patterns of canopy tree mortality shape forest stand structure and dynamics by influencing forest regeneration, species composition, growth rates, density, age structure, and tree regeneration and replacement (Weiskittel and Hix 2002, Woods 2004).

Most definitions of gaps restrict the gap to the area directly under the canopy opening within the forest where the canopy (leaf height of tallest stems) is noticeably lower than in adjacent areas in the forest canopy (Runkle 1992, Almquist et al. 2000, Hix et al. 2003). Gaps may range in area from the openings created by the death of a single branch to a larger scale 
blowdown of a catastrophic disturbance, such as a storm, a fire, or an aggregated insect outbreak (Kubo et al. 1996).

Quantifying gap patterns are crucial to understanding stand dynamics. The fundamental attributes of canopy gaps are their size, mode of origin, and shape, as these have the most effect on forest characteristics (Weiskittel and Hix 2002). Useful comparisons among forests include: 1) rates at which gaps form, 2) the total area occupied by gaps of different ages, 3) the gap area distribution, 4) the speed and mechanisms of gap closure, 5) fraction of land area under gaps (gap fraction), and 6) the method by which the gap forms (Runkle 1992, Battles et al. 1996, Anderson and Leopold 2002).

In eastern hardwood forests, gap size can vary widely by forest type but average sizes and range of sizes are similar (Runkle 1989). In the mixed mesophytic forests from Tennessee to Pennsylvania, average gap size is about $280 \mathrm{~m}^{2}$ with a majority of the gap sizes over $100 \mathrm{~m}^{2}$ (Table 1). Estimated turnover time, also known as the natural rotation time, in the mixed mesophytic region is about 140 years, ranging from 50- 270 years (Runkle 1982) (Table 1). In most northern hardwood forests, gap size ranges from a few $\mathrm{m}^{2}$ to $500 \mathrm{~m}^{2}$ except following intense disturbances (blow down, hurricanes, and fires) (Canham et al. 1990, DiGregorio et al. 1999, Lorimer and White 2003, Rebertus and Meier 2001, Weiskittel and Hix 2002, Hix et al. 2003).

Most gap studies of the mixed mesophytic forest type have occurred in small, mesic, oldgrowth remnants (Table 1). Gap phase replacement may begin prior to attainment of the old growth stage, when stands are still in the understory re-initiation phase (Oliver and Larson 1996). Old growth stands may not fully represent the gap phase dynamics of the second growth stands 
Table 1: Studies of gap dynamics in mixed mesophytic forests. Includes forest type, author, year, location, stage of development, average gap size $\left(\mathrm{m}^{2}\right)$, gap size range $\left(\mathrm{m}^{2}\right)$, gap fraction (\%), estimated turnover time (years), average cause of gap, and if topographical studies were assessed. Key: Oliver and Larson (1996) Stages of Development- OG= Old Growth, SG= Second Growth

\begin{tabular}{|c|c|c|c|c|c|c|c|c|c|c|c|c|c|c|c|c|c|}
\hline & 谤 & . & & . & & . & $\cdot$ & $\stackrel{\dddot{g}}{\approx}$ & $\ddot{g}$ & & . & & . & & . & 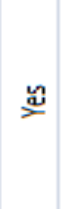 & $\stackrel{\square}{ \pm}$ \\
\hline & 윙 & $\begin{array}{l}\text { 言 } \\
\text { 产 } \\
\text { 音 }\end{array}$ & & 哭 & & $\begin{array}{l}\text { 总 } \\
\text { 음 } \\
\text { 음 }\end{array}$ & $\begin{array}{l}\text { 总 } \\
\text { 产 } \\
\text { 음 }\end{array}$ & $\stackrel{9}{\stackrel{9}{\dot{\theta}}}$ & 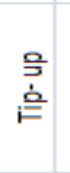 & 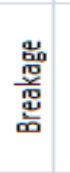 & . & & 量 & & . & . & 紊 \\
\hline & 圈 & . & & $\begin{array}{l}\stackrel{\circ}{9} \\
\text { ஸิ }\end{array}$ & & & $\stackrel{9}{9}$ & & $\cdot$ & 禀 & & 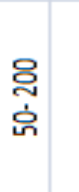 & 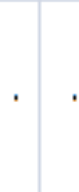 & & . & . & . \\
\hline & 웜원 & . & & 亗 & & . & 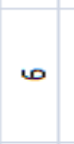 & & స్ పิ & r & & $\begin{array}{l}\dot{\Delta} \\
\stackrel{\dot{\sim}}{\dot{m}}\end{array}$ & 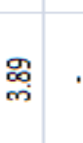 & . 음 & $m$ & . & . \\
\hline & 泀 & 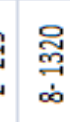 & $\stackrel{\text { 总 }}{\stackrel{1}{i}}$ & . & 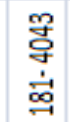 & $\begin{array}{l}\text { 勇 } \\
\text { 。্̊. }\end{array}$ & $\begin{array}{l}\stackrel{\infty}{\rightarrow} \\
\stackrel{\leftrightarrow}{\vec{t}}\end{array}$ & 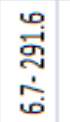 & . & 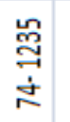 & 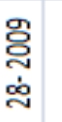 & 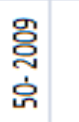 & . & . & . & . & 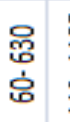 \\
\hline & 苟 & . & 总 & . & 舀 & . & 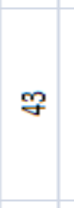 & 芯 & . & 点 & ఏ్రి & . & . & . & . & 岃 & $\Xi$ \\
\hline & 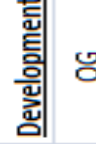 & 8 & 8 & 8 & . & $\because$ & $\mathbb{B}$ & . & $\mathscr{B}$ & 8 & 8 & 8 & 8 & 88 & $\mathbb{B}$ & 8 & $\cdot$ \\
\hline & 홓ㅇ & $z$ & $\gtrless$ & 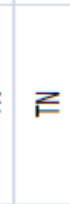 & $z$ & $\underline{z}$ & $\gtreqless$ & 등 & ऽ & zे & 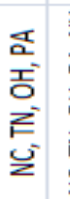 & 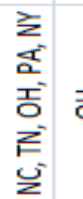 & 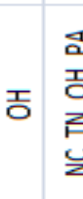 & 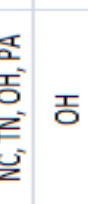 & 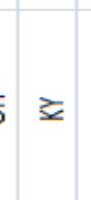 & $\gtreqless$ & z \\
\hline & 尌 高 & $\stackrel{8}{g}$ & 嵒 & 㟔 & 오 & 鸹 & 总 & 䍑 & 奇 & $\overrightarrow{\stackrel{g}{g}}$ & 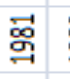 & 兽 & 㗊 合 & 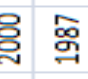 & $\stackrel{\Omega}{\stackrel{9}{9}}$ & $\stackrel{\mathscr{g}}{\stackrel{9}{9}}$ & 莺 \\
\hline & 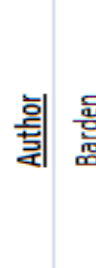 & 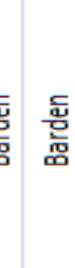 & $\begin{array}{l}\text { 咅 } \\
\text { 竞 }\end{array}$ & 哭 & 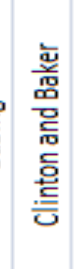 & 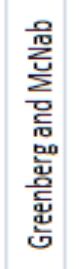 & 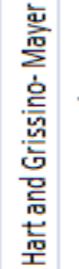 & 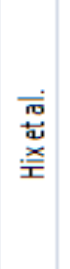 & 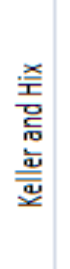 & 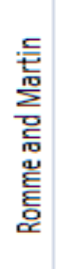 & 总 & & 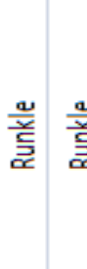 & 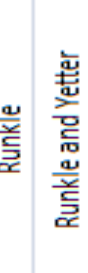 & 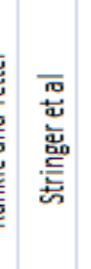 & 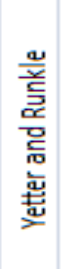 & 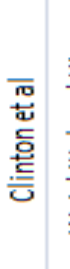 \\
\hline & 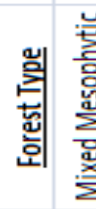 & 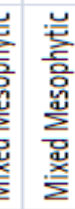 & 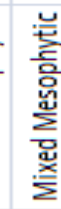 & 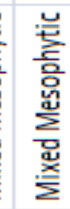 & 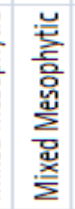 & 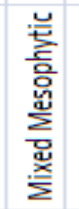 & 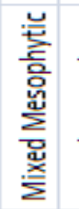 & 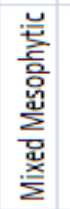 & 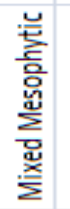 & 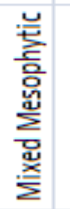 & 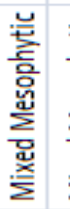 & $\begin{array}{l}\text { 訔 } \\
\text { 言 } \\
\text { 啇 } \\
\text { 旁 }\end{array}$ & 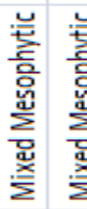 & 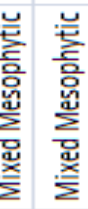 & 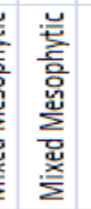 & 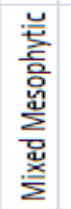 & 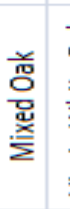 \\
\hline
\end{tabular}


that presently dominate the eastern deciduous forest (Keller and Hix 1999). Little direct evidence is currently available on how overall gap dynamics might differ among a broad range of developmental stages in temperate hardwood forests (Dahir and Lorimer 1996).

Gaps can be small for two reasons. First, they may be created by the death of a small canopy tree or by one branch. Second, they may be old, the remnants of larger openings almost closed by the lateral extension (branch) growth of canopy trees surrounding the gap (Whitmore 1989, Runkle 1992, Valverde and Silvertown 1997). Very small gaps in the forest canopy are likely to be filled by crown expansion (in-growth) from adjacent trees; otherwise gaps are filled by suppressed seedlings or saplings (Crow 1988).

Gaps usually form at rates of $\sim 1 \%$ of total land surface area per year (Runkle and Yetter 1987). In mixed mesophytic forests, gap fraction varied from 3- 25\% (Table 1). In general, gap fraction was larger in old growth forest than in second growth. Studies of forest gap dynamics have demonstrated that new gaps are more likely to occur adjacent to pre- existing gaps (Young and Hubbell 1991, Kubo et al. 1996). Trees in the gap border tend to have a higher rate of disturbance. Runkle (1984) re-censuses canopy gaps 4 years after his initial census and found that $11 \%$ of gaps had enlarged by blowdown of peripheral trees in the canopy and that $31 \%$ of gaps had enlarged because of the death of surrounding trees. These results suggest that repeat disturbance affecting the same location may be common (Runkle and Yetter 1987). As the fraction of gap sites increase, the average size of clusters of gap sites also increases. Eventually gaps merge with each other and form large gaps (Kubo et al. 1996).

Gap-makers are those that trees died and thus formed a gap (Runkle 1992). Tree mortality has important implications for succession because the individuals it removes may not 
be replaced (Franklin et al. 1987). Origin types, such as snags, blowdowns, and disease, are stand and region specific because tree mortality is closely related to various environmental variables and to community characteristics (Hix et al. 2003). Gap mode of origin has been shown to influence gap microenvironment and size, which affect the distribution of species regenerating within that stand (Weiskittel and Hix 2002).

The amount of resources made available depends on the number and size of trees that die. Resources may be made available instantaneously (i.e., light) or very slowly (i.e., nutrients and energy contained within the boles) (Franklin et al. 1987). Wind is one of the most frequent causes of large and small scale disturbance affecting eastern forests and is an important process in the creation of micro-topographic variation (Orwig and Abrams 1995, Clinton and Baker 2000).

Small scale disturbance in forests, such as single tree deaths, influence the abundance and composition of regeneration (Rantis and Johnson 2002). In forest communities where large scale disturbances are rare, tree species will depend on small gaps for establishment to eventually reach the overstory canopy (Clinton 2003).

Vegetation can reoccupy gaps by a combination of lateral extension of the crown of plants surrounding the gap, growth of advance regeneration, and establishment and growth of seedlings/ sprouts (Battles and Fahey 2000). While small gaps may be filled by horizontal growth of the crowns of adjacent trees, larger gaps are filled primarily by the upward growth of small trees (McClure et al. 2000). Environmental variables vary significantly among individual gaps, even among those in the same forest stand, contributing to diversity in canopy recruitment species (Almquist et al. 2000). Gaps may actively influence forest dynamics by altering the 
dispersal patterns, germination rates, recruitment rates, growth rates, and growth forms of tree species (Rankin and Tramer 2002).

Because of the variable capacity of tree species to tolerate shaded conditions, changes in canopy structure often lead to changes to the composition and level of competitiveness of trees in the understory (Frelich and Lorimer 1991). Changes in species composition may occur, as different shade intolerant and tolerant species are able to utilize gap resources, thereby "invading" the gap and temporarily increasing the species richness therein (Anderson and Leopold 2002). For example, recent studies of oak forests have suggested that replacement of oaks by more shade tolerant species (i.e., maple) is occurring on many sites (Taylor and Lorimer 2003).

Although individuals are recruited to larger size classes and higher vertical positions in these gaps, it may take multiple disturbance events for many sub canopy individuals to reach the main canopy level (Hart and Grissino-Mayer 2009). Saplings that do not reach the canopy during an initial period of release many eventually reach the canopy after 1-5 episodes of suppression before eventually growing into the canopy (Canham 1985, Runkle and Yetter 1987). Growth rates are higher and mortality lower for plants establishing before or soon after treefall (Runkle 1989). The vegetational composition of a gap at any given time should be a good predictor of its composition in the future (Runkle and Yetter 1987).

Eventually one or more individuals will dominate, closing the canopy opening and completing what has been termed the gap phase of the forest turnover cycle (Forrester and Runkle 2000). Runkle (1982) declared gaps closed when gap saplings prevent a ground observer 
from readily observing the canopy opening. He estimated that this will usually occur when trees are 10-20 $\mathrm{m}$ high in a forest with a 30-35 $\mathrm{m}$ tall canopy.

\section{Gap Dynamics and Topography}

Within the eastern deciduous forest of North America natural disturbance regimes are strongly correlated with broad geographic patterns of climate, topography, and soils, all of which influence the vegetation of a region (Runkle 1990, Rentch et al. 2003, Lorimer and White 2003). Factors such as topography, elevation, slope percent, aspect, slope position, weather patterns, light, moisture, disease, pests, and physiological characteristics of common tree species can affect the size and frequency of canopy disturbances (Clinton et al. 1994, Keller and Hix 1999, Fekedulegn et al. 2004).

Little research has been conducted concerning the effects of topography on gap dynamics in eastern forests. In Ohio, Hix et al. (2003) found that gap area did not vary significantly among four aspect classes, although exposed south facing slopes had more large gaps than small. Keller and Hix (1999) found no significant differences in gap fraction between north- and southfacing slopes, suggesting that aspect may not play a major role in the gap dynamics of secondgrowth forests in Ohio. In North Carolina, Clinton et al. (1994) discovered that ridges had a significantly greater total density of gaps than mid or lower slopes. 
CHAPTER 2

METHODOLOGY 


\section{Study Area}

The area under investigation is the 3100 ha West Virginia University Research Forest (WVURF), which lies $13.04 \mathrm{~km}$ east of Morgantown, WV (UTM: NAD 83, Zone $17 \mathrm{~N}$ ). The WVURF is located in Monongalia and Preston County and is a parcel of Coopers Rock State Forest (Figure 8).

The WVURF is typical of many Appalachian forests with long, steep and rocky slopes (Fekedulegn et al. 2004). The average elevation of the watershed is $224 \mathrm{~m}$ above sea level (Tajchman and Wiant 1983). The topography of the area is fairly rugged and the average slope inclination is $25 \%$. The average oak site index is $26.6 \mathrm{~m}$ at 50 years.

The bedrock for the area is upper connequenescing sandstone of the Pottsville series, which include conglomeratic sandstones, thin coals, fire clay, and shale which are highly resistant to erosion (USDA 1959). The soils are characterized as Dekalb soils on well- drained hill slopes and ridge tops, and deeper Ernest soils on concave slopes bordering streams (Fekedulegn et al. 2004). These are loamy- skeletal, moderately deep, and well- drained soils of low natural fertility (USDA 1959). Annual precipitation averages $129.4 \mathrm{~cm}$. The average temperature is 9 degrees $\mathrm{C}$. The frost free season averages 167 days (April 30 - October 10) (Rentch et al. 2002).

\section{Field Methods}

In the summer 2008, transect lines were digitized using GIS in ArcMap and were placed in areas of the WVURF (Figure 9) that avoided obvious large scale human caused disturbances, including silvicultural treatments, which had been applied to a fraction of the forest. Transect 


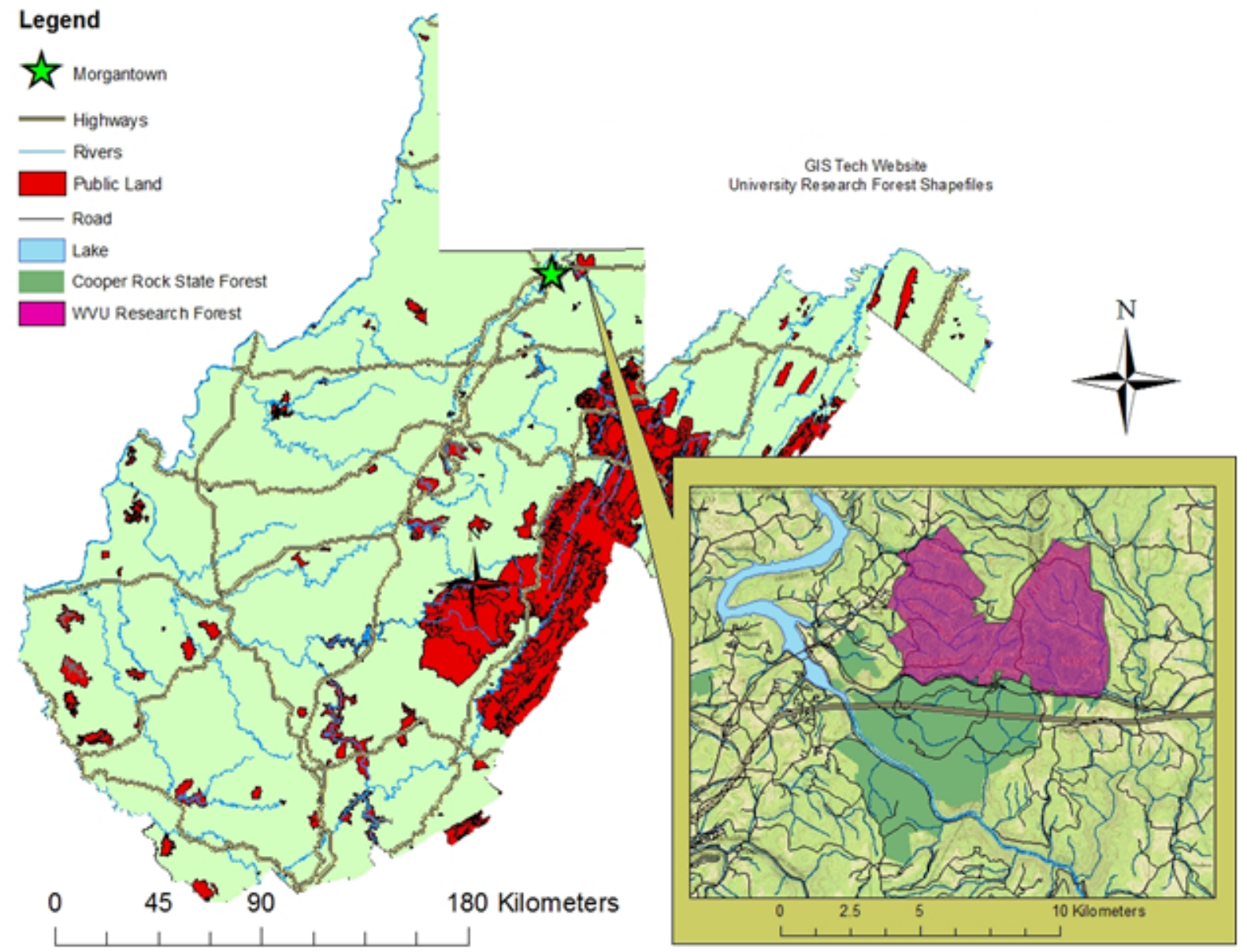

Figure 8: Location of the West Virginia University Research Forest. 


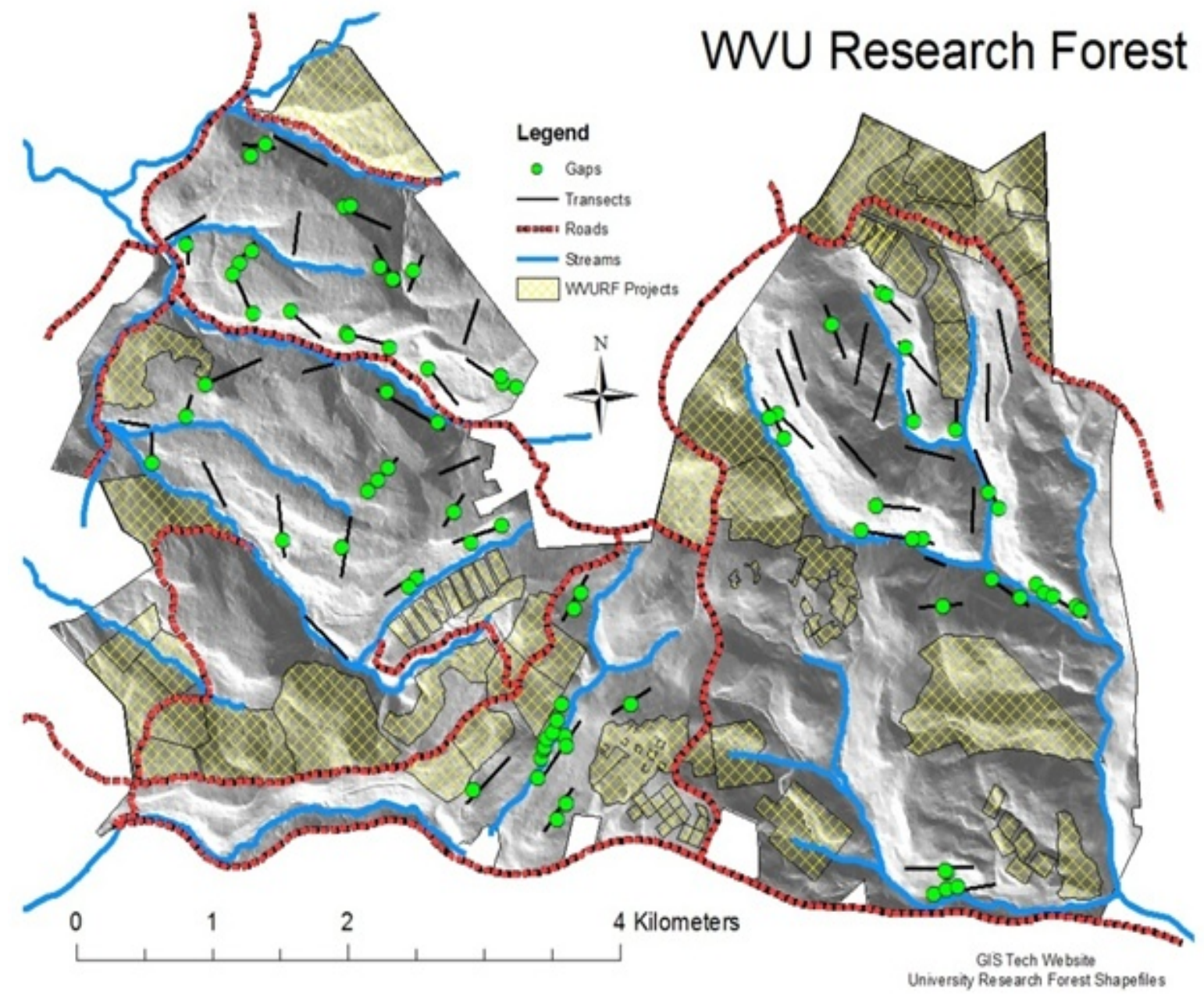

Figure 9: Transect location thoughout the West Virginia University Research Forest. Gaps found along transects represented by the green dots. WVURF projects indicate timber harvest areas. 
lines were delineated and strategically placed throughout the forest on ridges, mid- slopes, and coves. Cove transects were located within 50- $100 \mathrm{~m}$ of a stream (confirmed in the field visually).

A total of 61 transects were laid out for data collection, with a total length of $22,508 \mathrm{~m}$, and a mean length of $369 \mathrm{~m}$. Each transect had two points, a beginning and an end. These points were loaded into a GPS unit to instruct the field workers where they needed to work and what distances they had already gone.

Every 25- $50 \mathrm{~m}$ along a transect line, the composition of living trees was determined using the point- centered quarter method (Cottam and Curtis 1956). This method examines a sub- sample of the forest in order to determine species composition of the transect line. In each quarter, dbh and species of the nearest trees $\geq 25 \mathrm{~cm}$ dbh were measured.

The definition of a canopy gap was important for determining if an opening along a transect would be sampled. By definition, a gap is an opening in the canopy created by the death of at least one tree (Runkle 1992). Two types of gaps were defined. The canopy gap was the land surface area directly under the canopy opening. The expanded gap consisted of the canopy gap plus the adjacent area extending to the bases of canopy trees surrounding the canopy gap. The expanded gap is useful to analyze because it includes the area directly and indirectly affected by the canopy opening because sunlight rises and lowers at an angle. Gaps were considered closed or indistinguishable from the background overstory when the regeneration within the gaps was approximately 10- $20 \mathrm{~m}$ high (Runkle 1982).

In some forests small areas are free from trees for a very long period due to soil, bedrock, or other biological factors. These "gaps" may resemble canopy gaps in composition, structure, 
and function of biota but not in their dynamics (Runkle 1992). Therefore, only gaps that were formed by the death of at least one canopy tree were considered.

A gap was considered for data collection if any part of the gap itself crossed the transect line. If the gap did not intersect the transect line it was not considered (Figure 10). The first measurement taken after establishing a gap was the GPS point (UTM). The second measurement taken was of the portion of the transect intersecting the gap in order to determine the fraction of total land in gaps (gap fraction). The number of meters along the transect in each canopy gap was recorded (Figure 11). The area (A) for each gap intersected by transects was estimated by fitting gap length (L) (largest distance from gap edge to gap edge) and width (W) (largest distance perpendicular to the length) to the formula for an ellipse; $A=\pi \mathrm{LW} / 4$. A maximum gap size threshold was set at $1000 \mathrm{~m}^{2}$ (Barden 1981, Collins and Pickett 1982, Runkle 1992, Almquist et al. 2000).

The number and species of tree(s) creating the gap (gap-maker) was also noted (Figure 12). The origin of each gap was classified into four groups: blow-down, snag, decay, or grape vine. Blow-down was any tree that had tipped over, but not necessarily including a stump pit and mound. A snag was any standing dead tree. Decay was due to heart rot that weakened the bowl. Finally, grape vine gaps were created by the vines pulling down trees and snapping off their trunks. In addition, aspect was recorded for each gap. Aspect was classified in four quadrants of $90^{\circ}$ each (northeast $0-90^{\circ}$, southeast $91-180^{\circ}$, southwest $181-270^{\circ}$, northwest 271 $\left.360^{\circ}\right)$. Also, three, $1 \mathrm{~m}^{2}$ plots were established at the beginning, middle, and end of each gap to assess gap regeneration. Any seedlings or sapling $\leq 10 \mathrm{~m}$ in height were recorded for its species and height (to the nearest $0.25 \mathrm{~m}$ ). 


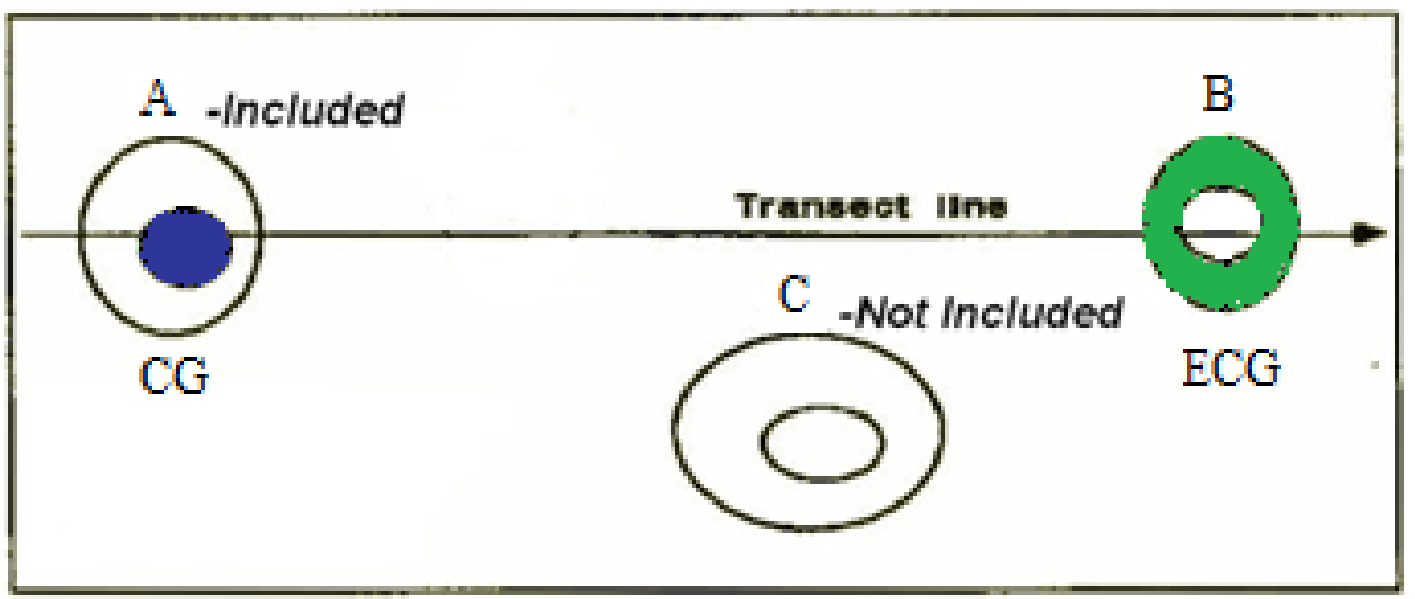

Figure 10: Method used for selecting gaps. Any gap that intersects the transect (A, B) was included in the analysis, while $\mathrm{C}$ was not. A. highlights in blue the canopy gap (CG), B. highlights in green the expanded canopy gap (ECG). 


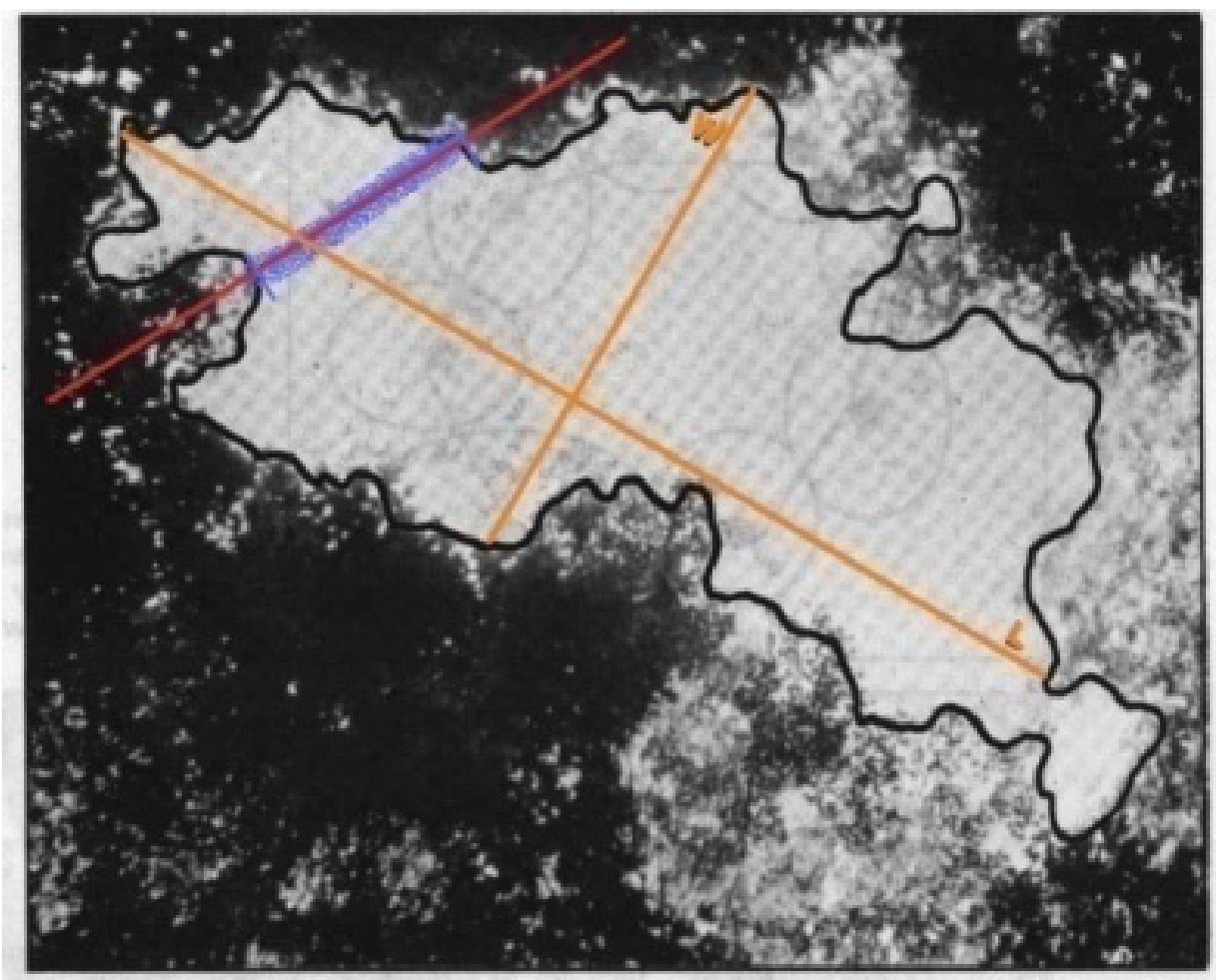

Figure 11: Canopy gap caused by the death of one or more trees. Transect is the line in red, blue represents the distance of the transect in gaps, and length and width of the canopy gap are in orange. 


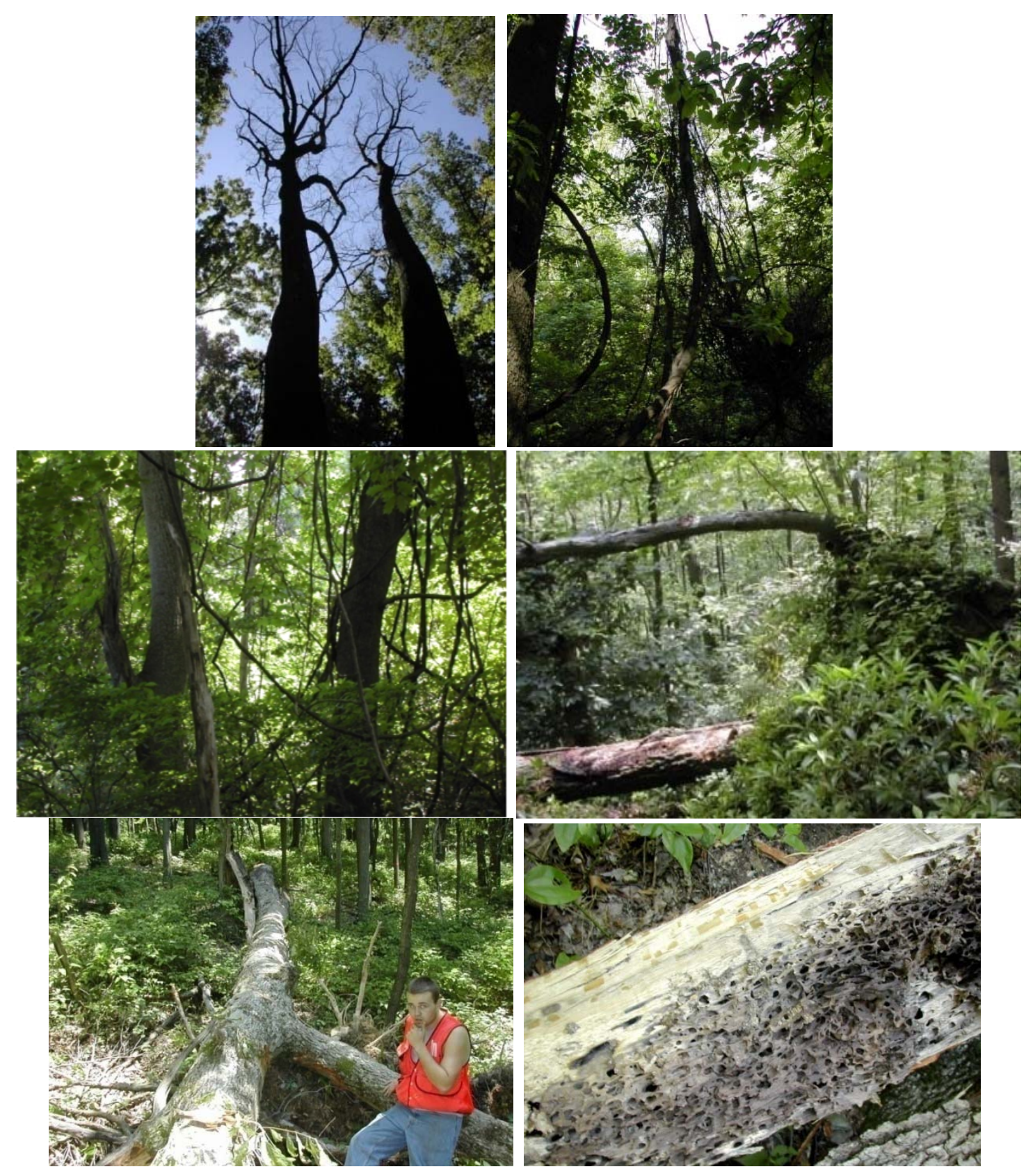

Figure 12: Examples of gap-makers (top left- snag, top right and middle left- grape vines, middle right and middle left- blow-down, and bottom right- decay). 
To determine the age of the gap two trees near each gap were cored. These trees needed to have appeared to have received resources that the gap "released". Trees with obvious bole defects were not cored. Tree cores were extracted at breast height and transferred to the laboratory in straws. Cores were air dried, mounted, and sanded with three levels of sand paper. Annual growth rings were measured with a Leica binocular microscope and Velmex measuring stage to the nearest $0.001 \mathrm{~mm}$. Data output were recorded using J2X software. The notebook file created from the J2X software was converted into an Excel file for analysis.

\section{Data Analysis}

To describe species composition along each transect for trees $\geq 25 \mathrm{~cm}$ dbh, calculations were made using equations 1,2 , and 3 to determine relative density, relative basal area, and relative frequency.

$\begin{array}{lcl}\text { Equation } 1 & \text { Relative Density }=\underline{\text { individuals of species A }} \times 100 \\ \text { total individuals of all species } & \text { Relative Basal Area }=\frac{\text { total basal area of species A }}{\text { total basal area of all species }} \times 100 \\ \text { Equation 2 } & \text { Relative Frequency }=\frac{\text { frequency value for species A }}{\text { total frequency value for all species }} \times 100 \\ & \text { Where: Frequency }=\frac{\text { number of points at which species A occurs }}{\text { total number of points sampled }} \times 100\end{array}$

Importance values (IV) were derived from the sum of the relative density, relative basal area, and relative frequency/3. Forest cover types were determined from the species IVs. Cove hardwoods contained a majority ( $>50 \%)$ of the IVs in yellow-poplar (Liriodendron tulipifera), black cherry (Prunus serotina), and red maple (Acer rubrum). Mesic Oak included $>50 \%$ of IVs 
in northern red oak (Quercus rubra), yellow poplar, and red maple. Xeric oak included $>50 \%$ of IVs in northern red oak, scarlet oak (Quercus coccinea), and chestnut oak (Quercus prinus).

The gap fraction is the sum of all forest area under gaps at one time, expressed at a percentage of the total area. Gap fraction was determined by dividing the transect distance in gaps by the total transect distance following Runkle $(1985,1992)$.

For the regeneration in each gap, species IVs were calculated by averaging the values of the three regeneration plots within that gap. I computed two measurements by species: relative density and relative height (equations 4 and 5). Importance values were determined by summing relative density and relative height / 2 .

Equation 4 Relative Density $=\frac{\text { number of individual of species A }}{\text { total individuals of all species }} \times 100$

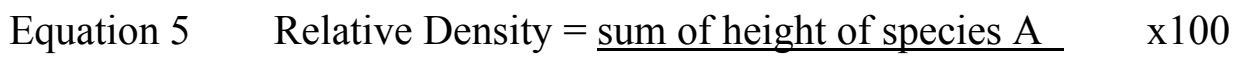
total sum height of all species

Disturbance would be expected to cause abrupt and sustained increases in growth of trees "released" by the death of nearby overstory trees and also increased growth of some of the adjacent surviving trees in the upper crown classes. The number of trees responding to the release would depend on the severity of the disturbance (Lorimer 1980, Fraver and White 2005). I used equation 6 to calculate percent growth change of cores extracted from released trees.

Equation $6 \quad \begin{aligned} & \text { Percent Growth Change }(\% \mathrm{GC})=[(\mathrm{M} 2-\mathrm{M} 1) / \mathrm{M} 1] \times 100 \\ & \text { Percent Growth Change = percent growth change between } \\ & \text { preceding and subsequent } 10 \text { year means, } \mathrm{M} 1=\text { preceding } 10 \text { year } \\ & \text { mean (inclusive of the disturbance year), and } \mathrm{M} 2=\text { subsequent } 10 \\ & \text { year mean. }\end{aligned}$


Three levels of crown release were recognized and modified by Nowacki and Abrams, based on more leant criteria set up by Lorimer and Frelich (1989). 1) Major releases were defined as events where $\% \mathrm{GC} \geq 100$ (complete overhead releases of smaller overtopped samplings and pole sized trees). 2) Moderate releases were classified as those with a \%GC of $50-99 \%$. 3) Minor releases caused by increased side light to a tree already in the over story, or a neighbors death in the self thinning process were classified as those with \%GC 25-49\% (Rentch et al. 2003).

The maximum percentage growth response associated with a given disturbance was found to be directly tied to the year of probable canopy perturbation (Nowacki and Abrams 1997). A precise correlation does not always exist between peak $\% \mathrm{GC}$ as calculated. Differences in individual tree genetics and physiological condition before the disturbance and peak disturbance event were initially assigned a 3 year window (Rentch et al. 2003). However, Nowacki and Abrams proposed a one year lag interval to allow for the tree to respond to the disturbance (Rentch et al. 2003). Therefore a single year was assigned soon after (Rentch et al. 2003). If two releases occurred, the most recent (younger) release date was used.

Oscillations in temperature during the growing season (temperature, precipitation) exerted a significant influence on annual tree ring variation; however it was significantly less pronounced than non climatic events such as crown release and canopy disturbance (Lorimer 1980, Rentch et al. 2003).

Analysis of Variance (ANOVA) was performed using SAS (Statistical Analysis Software) to compare gap area, gap age, gap fraction, and regeneration IVs with slope position, aspect, and forest type. A square root transformation (appropriate when there is a Poisson 
distribution) was applied to the data from gap area and expanded gap area. Arc-sin square root transformation was applied to gap fraction and regeneration IVs. This transformation is used when there is a proportional distribution and non continuous data. No transformation was applied to gap age. The multiple comparison procedure for gap area, fraction, and regeneration was Duncan's new multiple- range test. Gap age was analyzed by Student- Newman- Keuls' procedure. Statistical significance for all tests were accepted at $\alpha \leq 0.05$ (Dowdy et al. 2004). 
CHAPTER 3

RESULTS 


\section{Forest Composition}

The predominant species in this forest are red maple, yellow poplar, black cherry, white oak (Quercus alba), northern red oak, scarlet oak, chestnut oak, and black birch (Betula lenta) (Table 2). Xeric oak and mesic oak forest types contained almost equal numbers of transects with 28 and 24 and captured $8930.86 \mathrm{~m}$ of transects $(40.66 \%)$ and $10507.48 \mathrm{~m}$ of transects (45.95\%), respectively. Cove hardwoods comprised the least amount of transects with only 8 , securing $2604.27 \mathrm{~m}$ of transect $(13.40 \%)$.

\section{Gap Size}

Eighty gaps were identified along 61 transects (Table 3). Southwest aspects comprised the most gaps (45\%) followed by southeast (22.5\%), northwest (18.75\%), and northeast (13.75\%). Mid- slope positions dominated by containing $52.5 \%$ of gaps, followed by cove with $28.75 \%$ of gaps, and ridge with $18.75 \%$ of gaps. Xeric oak and mesic oak forest types contained almost equal numbers of gaps with $46.25 \%$ and $37.5 \%$, respectively. Cove hardwoods possessed the least amount of gaps with only $16.25 \%$.

The average canopy gap size was $98.59 \mathrm{~m}^{2}( \pm 134.17)$. The minimum gap size found in the WVURF was $5.75 \mathrm{~m}^{2}$, while the largest gap size was $962.88 \mathrm{~m}^{2}$ (Table 3). Figure 13 shows the canopy gap area distribution of gap size classes. The distribution is skewed to the left with most gaps smaller than $100 \mathrm{~m}^{2}$.

Mean gap size did not vary by aspect or slope position. However, gaps were significantly larger $(\mathrm{P}=0.0145)$ in cove hardwoods than in the mesic oak and xeric oak forest types. Gaps in cove hardwoods averaged $192.76 \mathrm{~m}^{2}( \pm 70.03)$ in size, while mean gap size in mesic and xeric oaks was $90.38( \pm 25.39)$ and $72.16( \pm 8.23)$, respectively (Table 3$)$. There were no significant interactions between forest type, aspect, and topographic position. 
Table 2: Species importance values by forest type on the West Virginia University Research Forest.

\begin{tabular}{c|c|c|c|c} 
Forest Cover Type & \multicolumn{1}{c}{ Cove Hardwood } & \multicolumn{1}{c}{ Mesic Oak } & \multicolumn{1}{c}{ Xeric Oak } & \multicolumn{1}{c}{ Total } \\
\hline Number of Transects & 9 & 24 & 28 & 61 \\
\hline White Oak & 0.76 & 4.88 & 5.67 & 4.63 \\
Northern Red Oak & 11.14 & 33.14 & 27.26 & 27.19 \\
Chestnut Oak & 5.59 & 7.43 & 24.34 & 14.92 \\
Other Oak & 5.42 & 4.20 & 11.69 & 7.55 \\
Black Cherry & 4.73 & 7.22 & 0.68 & 3.85 \\
Yellow Poplar & 47.90 & 17.47 & 6.06 & 16.72 \\
Maple b & 12.79 & 15.37 & 13.07 & 14.08 \\
Black Birch & 3.80 & 3.63 & 2.14 & 2.97 \\
Other $_{\text {c }}$ & 7.87 & 6.67 & 9.10 & 8.09
\end{tabular}

a) includes black oak (Quercus velutina) and scarlet oak,

b) mostly red maple with small amounts of sugar maple (Acer saccharum),

c) includes all the other species: american beech (Fagus grandifolia), american basswood (Tilia americana), black gum (Nyssa sylvatica), black locust (Robinia pseudoacacia), cucumber tree (Magnolia acuminata), pignut hickory (Carya glabra), sourwood (Oxydendrum arboreum), white ash (Fraxinus americana), and yellow birch (Betula alleghaniensis) 
Table 3: Gap size $\left(\mathrm{m}^{2}\right)$ characteristics varying by aspect, slope position, and forest type on the West Virginia University Research Forest. ANOVA (Proc GLM) was used to determine any differences, while Duncan's test was used to identify what means are different. Means denoted by different letters differ significantly in their square root transformations at the 0.05 probability level.

\begin{tabular}{|c|c|c|c|c|c|c|}
\hline$\underline{\text { Aspect }}$ & $\frac{\text { P-Value }}{0.2361}$ & $\begin{array}{l}\text { Number } \\
\text { of Gaps }\end{array}$ & Mean $\left(\mathrm{m}^{2}\right)$ & $\underline{\text { Std Error }}$ & Minimum & Maximum \\
\hline $\mathrm{NE}$ & & 11 & $99.51_{\mathrm{a}}$ & 27.31 & 6.29 & 302.49 \\
\hline NW & & 15 & $148.13 \mathrm{a}$ & 61.79 & 9.04 & 962.88 \\
\hline SE & & 18 & $112.97 \mathrm{a}$ & 40.77 & 27.06 & 779.61 \\
\hline SW & & 36 & $70.48_{\mathrm{a}}$ & 8.82 & 5.75 & 247.50 \\
\hline Slope Position & 0.1889 & & & & & \\
\hline Cove & & 23 & $121.54_{\mathrm{a}}$ & 33.52 & 6.29 & 779.61 \\
\hline Mid & & 42 & $100.41_{\mathrm{a}}$ & 23.29 & 5.75 & 962.88 \\
\hline Ridge & & 15 & $58.30_{\mathrm{a}}$ & 9.81 & 9.04 & 150.27 \\
\hline Forest Type & 0.0145 & & & & & \\
\hline Cove Hardwood & & 13 & $192.76_{b}$ & 70.03 & 6.29 & 962.88 \\
\hline Mesic Oak & & 30 & $90.38 \mathrm{a}$ & 25.39 & 9.04 & 779.61 \\
\hline Xeric Oak & & 37 & $72.16_{\mathrm{a}}$ & 8.23 & 5.75 & 247.50 \\
\hline Total & & 80 & 98.59 & 134.17 & 9.03 & 617.52 \\
\hline
\end{tabular}




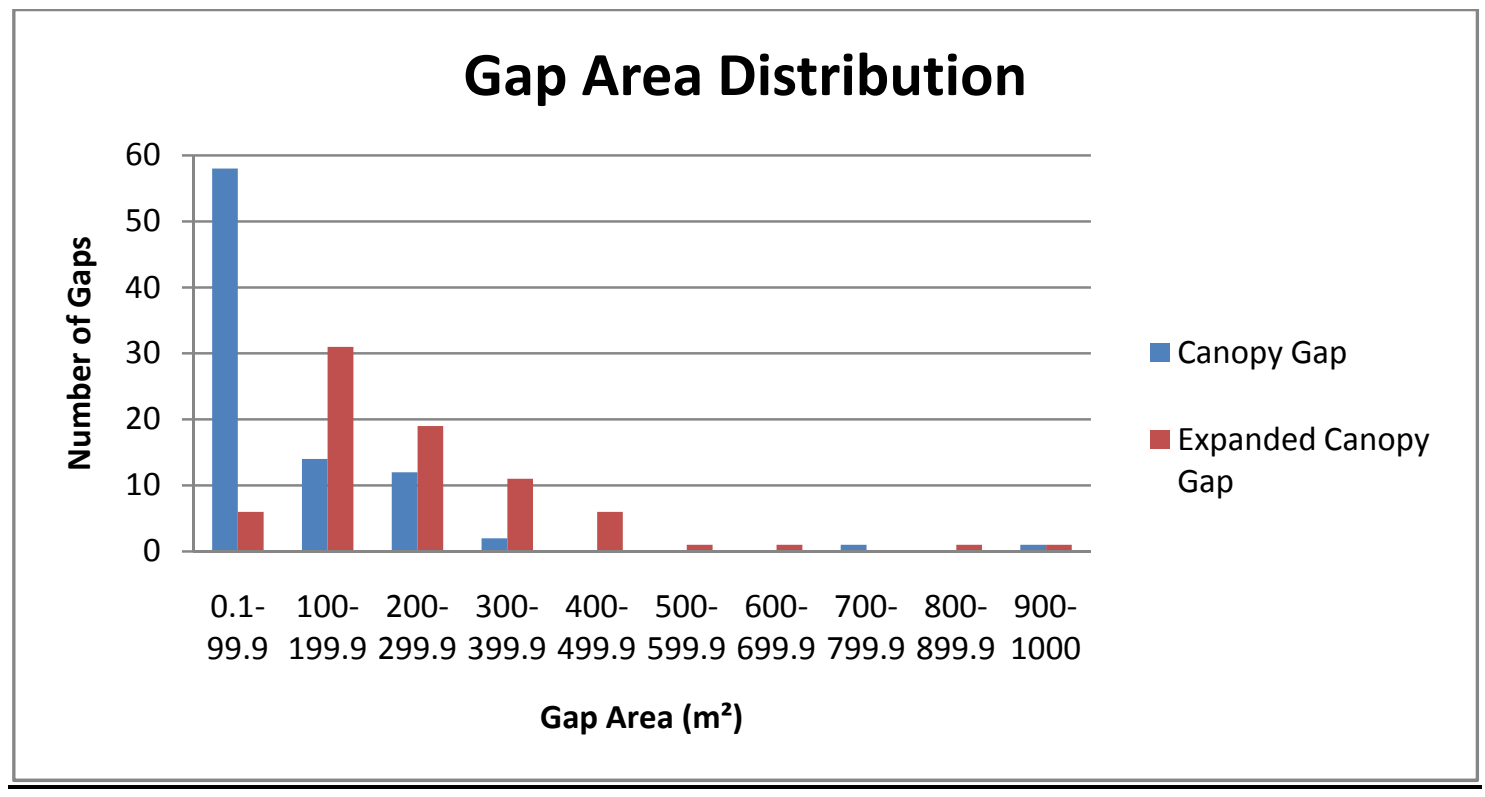

Figure 13: Distribution of gap size classes on the West Virginia University Research Forest. 
The average expanded gap size was $287.64 \mathrm{~m}^{2}( \pm 238.49)$. The minimum expanded gap size found in the WVURF was $43.31 \mathrm{~m}^{2}$, while the largest gap size was $1820.07 \mathrm{~m}^{2}$ (Table 4). Mean expanded gap size did not vary by slope position. Gaps on northwest slopes were significantly larger $(\mathrm{P}=0.0188)$ than southwest slopes. Expanded gaps on northwest aspects averaged $422.09 \mathrm{~m}^{2}( \pm 120.38)$ in size, while expanded gap size on southeast, northeast, and southwest aspects averaged $320.84 \mathrm{~m}^{2}( \pm 69.70), 289.68 \mathrm{~m}^{2}( \pm 59.51)$, and $214.39 \mathrm{~m}^{2}( \pm 17.34)$, respectively (Table 4). Expanded gaps were significantly larger $(\mathrm{P}=0.0001)$ in cove hardwoods than in the mesic oak and xeric oak forest types. Expanded gaps in cove hardwoods averaged $537.08 \mathrm{~m}^{2}( \pm 128.94)$ in size, while mean gap size in mesic and xeric oaks was $256.11 \mathrm{~m}^{2}( \pm$ 45.76) and $225.56 \mathrm{~m}^{2}( \pm 17.02)$, respectively (Table 4$)$. There were no significant interactions between aspect, slope position, and forest type.

\section{Gap Age}

Although 80 gaps were identified, only 57 were available for gap age analysis due to limitations when using radial growth analysis to determine age. Gap age ranged from 2-29 years old with a mean age of 16.42 years $( \pm 6.3)$ (Table 5). Figure 14 shows the distribution of gap age classes. Mean gap age did not vary significantly by aspect, slope position, or forest type. The gap formation rate per year was determined by dividing the percent of land in gaps by the average age yielding $0.165 \%$. The approximate time for the forest to completely turnover is 604.4 years. This was calculated by taking the gap formation rate to the -1 power. Turnover time will change over time and though stages of development. 
Table 4: Expanded gap size $\left(\mathrm{m}^{2}\right)$ characteristics varying by aspect, slope position, and forest type on the West Virginia University Research Forest. ANOVA (Proc GLM) was used to determine any differences, while Duncan's test was used to identify what means are different. Means denoted by different letters differ significantly in their square root transformations at the 0.05 probability level.

\begin{tabular}{|c|c|c|c|c|c|c|}
\hline Aspect & $\frac{\text { P-Value }}{0.0188}$ & $\begin{array}{l}\text { Number } \\
\text { of Gaps }\end{array}$ & Mean $\left(\mathrm{m}^{2}\right)$ & $\underline{\text { Std Error }}$ & Minimum & Maximum \\
\hline NE & & 11 & $289.68_{\mathrm{ab}}$ & 59.51 & 58.34 & 635.24 \\
\hline NW & & 15 & $422.09 \mathrm{a}$ & 120.38 & 43.31 & 1820.07 \\
\hline SE & & 18 & $320.84_{\mathrm{ab}}$ & 69.70 & 135.34 & 1419.17 \\
\hline SW & & 36 & $214.39_{b}$ & 17.34 & 87.65 & 490.28 \\
\hline Slope Position & 0.2578 & & & & & \\
\hline Cove & & 23 & $317.04 \mathrm{a}$ & 59.32 & 58.34 & 1419.17 \\
\hline Mid & & 42 & $300.82_{\mathrm{a}}$ & 46.84 & 43.31 & 1820.07 \\
\hline Ridge & & 15 & $205.64_{\mathrm{a}}$ & 21.41 & 106.86 & 331.47 \\
\hline Forest Type & 0.0001 & & & & & \\
\hline Cove Hardwood & & 13 & $537.08_{b}$ & 128.94 & 58.34 & 1820.07 \\
\hline Mesic Oak & & 30 & $256.11_{\mathrm{a}}$ & 45.76 & 43.31 & 1419.17 \\
\hline Xeric Oak & & 37 & $225.56_{\mathrm{a}}$ & 17.02 & 87.65 & 490.28 \\
\hline Total & & 80 & 287.64 & 238.49 & 72.25 & 1166.50 \\
\hline
\end{tabular}


Table 5: Gap age (years) varying by aspect, slope position, and forest type on the West Virginia University Research Forest. ANOVA (Proc GLM) was used to determine any differences, while SNK's test was used to identify what means are different. Means denoted by different letters differ significantly at the 0.05 probability level.

\begin{tabular}{|c|c|c|c|c|c|c|}
\hline Aspect & $\frac{\text { P-Value }}{0.1366}$ & $\begin{array}{l}\text { Number } \\
\text { of Gaps }\end{array}$ & Mean (years) & $\underline{\text { Std Error }}$ & Minimum & Maximum \\
\hline $\mathrm{NE}$ & & 9 & $13.67 \mathrm{a}$ & 1.72 & 11 & 26 \\
\hline NW & & 10 & $15.70_{\mathrm{a}}$ & 1.64 & 11 & 27 \\
\hline $\mathrm{SE}$ & & 12 & $13.83 \mathrm{a}$ & 1.07 & 10 & 21 \\
\hline SW & & 26 & $18.85_{\mathrm{a}}$ & 1.53 & 2 & 29 \\
\hline Slope Position & 0.6012 & & & & & \\
\hline Cove & & 20 & $17.35 \mathrm{a}$ & 1.52 & 8 & 29 \\
\hline Mid & & 30 & $16.23 \mathrm{a}$ & 1.23 & 2 & 29 \\
\hline Ridge & & $\underline{7}$ & $14.57_{\mathrm{a}}$ & 2.11 & 11 & 26 \\
\hline Forest Type & 0.1507 & & & & & \\
\hline Cove Hardwood & & 10 & $12.30_{\mathrm{a}}$ & 1.51 & 2 & 19 \\
\hline Mesic Oak & & 24 & $17.33_{\mathrm{a}}$ & 1.47 & 8 & 29 \\
\hline Xeric Oak & & 23 & $17.26_{\mathrm{a}}$ & 1.27 & 10 & 29 \\
\hline Total & & 57 & 16.42 & 6.30 & 7.50 & 26.40 \\
\hline
\end{tabular}




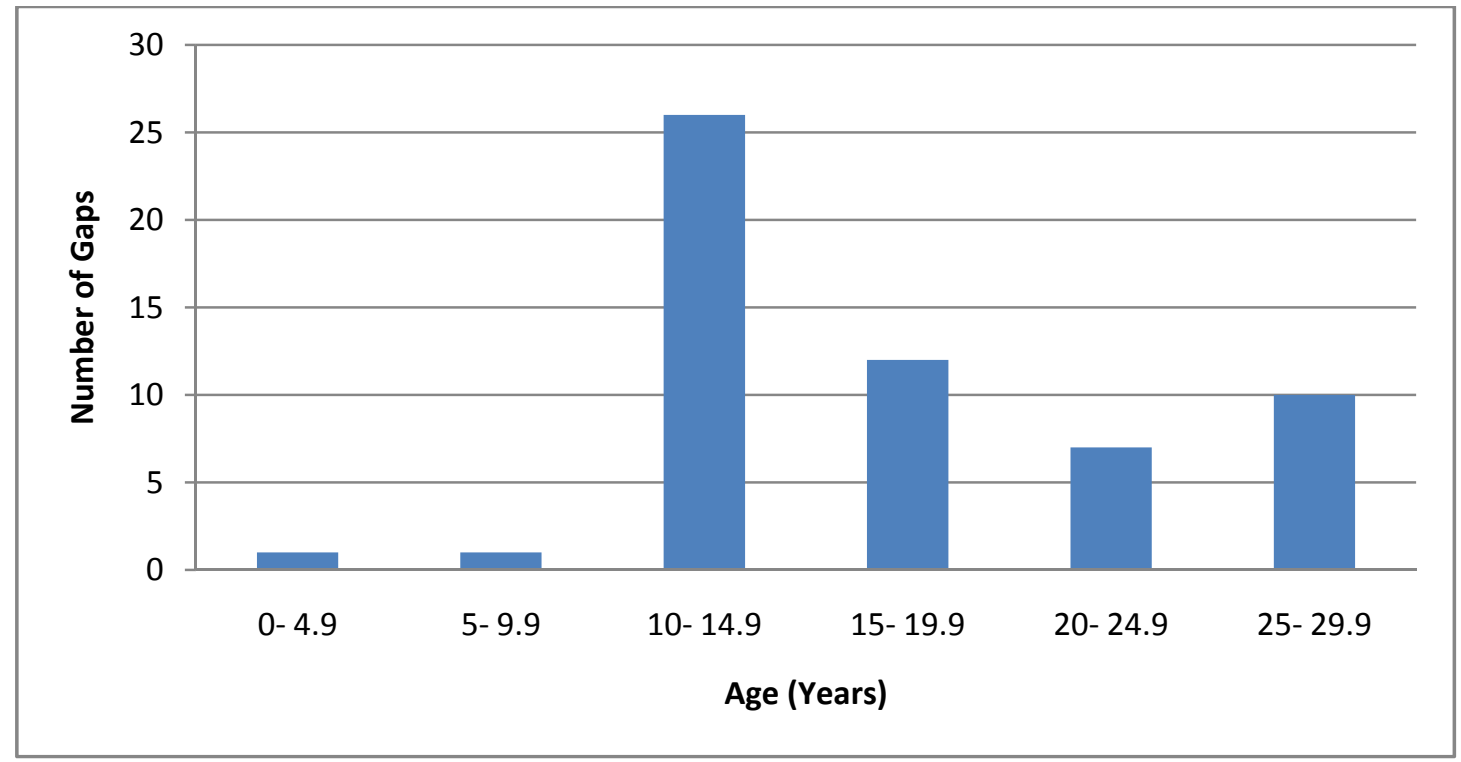

Figure 14: Distribution of gap age classes on the West Virginia University Research Forest. Gap age $<10$ years are under estimated due to use of radial growth averaging technique to estimate gap age. 


\section{Gap Fraction}

The average gap fraction along 61 transects in the WVURF was $2.73 \%( \pm 2.48 \%)$. The range of gap fraction for each transect was $0 \%$ (no gaps) - $13.06 \%$. Mean gap fraction did not vary by slope position. Gap fraction on southeast aspects was significantly larger $(\mathrm{P}=0.0021)$ than southwest and northeast slopes. Gaps on southeast aspects averaged $5.32 \%( \pm 2.07)$, while mean gap fraction in northwest, southwest, and northeast was $4.34 \%( \pm 1.23), 2.36 \%( \pm 0.45)$, and $1.88 \%( \pm 0.76)$, respectively (Table 6$)$. Gappinness were significantly larger $(\mathrm{P}=0.0062)$ in cove hardwoods than in the mesic oak and xeric oak forest types. Gaps in cove hardwoods averaged $5.29 \%( \pm 1.62)$, while mean gap fraction in mesic and xeric oaks was $2.19 \%( \pm 0.58)$ and $2.47 \%( \pm 0.45)$, respectively (Table 6$)$. There were no significant interactions between forest type, aspect, and slope position.

\section{Gap Regeneration}

Figure 15 shows gap importance values of gap regeneration. While oak is the most abundant species group regenerating in gaps, there is a mixture of species, including black cherry, maple, black birch, and understory shrubs such as spice bush (Lindera benzoin). Oak regeneration IVs did not vary by aspect or forest type. However, gaps had significantly larger oak IVs $(\mathrm{P}=0.0293)$ in coves and mid- slopes than in ridge slope positions. Gaps in ridges averaged oak IVs of $10.17( \pm 19.46)$, while mean gap oak IV's in coves and mid- slopes was $30.40( \pm 32.86)$ and $27.63( \pm 33.42)$, respectively (Table 7). There were no significant interactions between forest type, aspect, and slope position. 
Table 6: Gap fraction varying by aspect, slope position, and forest type on the West Virginia University Research Forest. ANOVA (Proc GLM) was used to determine any differences, while Duncan's test was used to identify what means are different. Means denoted by different letters differ significantly in their arc-sin square root transformations at the 0.05 probability level.

\begin{tabular}{|c|c|c|c|c|c|c|}
\hline Aspect & $\frac{\text { P-Value }}{0.0021}$ & $\begin{array}{l}\text { Number of } \\
\text { Transects } \\
\end{array}$ & Mean $(\%)$ & Std Error & Minimum & Maximum \\
\hline $\mathrm{NE}$ & & 15 & $1.88_{\mathrm{c}}$ & 0.76 & 0.00 & 9.02 \\
\hline NW & & 9 & $4.34_{\mathrm{ab}}$ & 1.23 & 0.44 & 13.06 \\
\hline SE & & 4 & $5.32 \mathrm{a}$ & 2.07 & 2.77 & 11.44 \\
\hline SW & & 32 & $2.36_{b c}$ & 0.45 & 0.00 & 8.91 \\
\hline Slope Position & 0.8681 & & & & & \\
\hline Cove & & 15 & $2.45_{\mathrm{a}}$ & 0.91 & 0.00 & 11.44 \\
\hline Mid & & 32 & $3.10_{\mathrm{a}}$ & 0.56 & 0.00 & 13.06 \\
\hline Ridge & & 13 & $2.17 \mathrm{a}$ & 0.58 & 0.00 & 6.72 \\
\hline Forest Type & 0.0062 & & & & & \\
\hline Cove Hardwood & & 8 & $5.29_{b}$ & 1.62 & 0.00 & 13.06 \\
\hline Mesic Oak & & 24 & $2.19 \mathrm{a}$ & 0.58 & 0.00 & 11.44 \\
\hline Xeric Oak & & 28 & $2.47 \mathrm{a}$ & 0.45 & 0.00 & 8.91 \\
\hline Total & & 61 & 2.73 & 2.48 & 0.32 & 10.71 \\
\hline
\end{tabular}




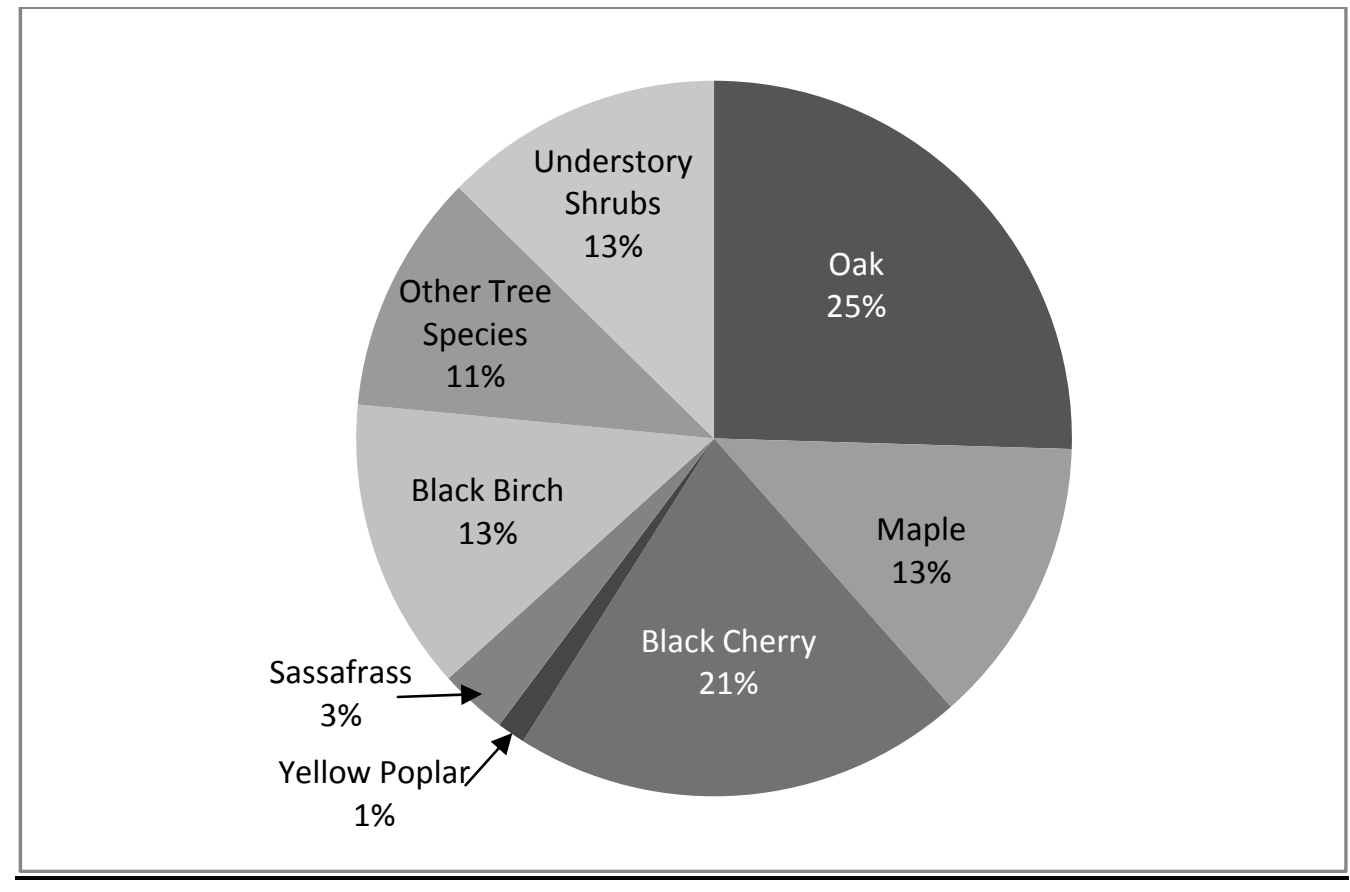

Figure 15: Species importance values for regeneration within gaps on the West Virginia University Research Forest. 
Table 7: Oak regeneration importance values varying by aspect, slope position, and forest type on the West Virginia University Research Forest. ANOVA (Proc GLM) was used to determine any differences, while Duncan's test was used to identify what means are different. Means denoted by different letter differ significantly in their arc-sin square root transformations at the 0.05 probability level.

\begin{tabular}{|c|c|c|c|c|}
\hline & $\underline{\text { P-Value }}$ & & \multicolumn{2}{|c|}{$\frac{\text { IV OF OAK }}{\underline{\text { REGEN }}}$} \\
\hline Aspect & 0.2432 & Number of Gaps & Mean & $\underline{\text { Std Error }}$ \\
\hline $\mathrm{NE}$ & & 11 & $6.28_{a}$ & 13.89 \\
\hline NW & & 15 & $11.81_{\mathrm{a}}$ & 28.24 \\
\hline SE & & 18 & $17.83_{\mathrm{a}}$ & 23.77 \\
\hline SW & & 36 & $40.13_{\mathrm{a}}$ & 34.13 \\
\hline Slope Position & 0.0293 & & & \\
\hline Cove & & 23 & $30.40 \mathrm{a}$ & 32.86 \\
\hline Mid & & 42 & $27.63 \mathrm{a}$ & 33.42 \\
\hline Ridge & & 15 & $10.17_{b}$ & 19.46 \\
\hline Forest Type & 0.1016 & & & \\
\hline Cove Hardwood & & 13 & $11.85 \mathrm{a}$ & 22.59 \\
\hline Mesic Oak & & 30 & $14.15_{\mathrm{a}}$ & 24.32 \\
\hline Xeric Oak & & 37 & $38.74_{\mathrm{a}}$ & 34.58 \\
\hline Total & & 80 & 25.15 & 26.73 \\
\hline
\end{tabular}




\section{Gap-makers}

The average number of gap-makers per gap was $2.46( \pm 2.42)$. However, the most frequent (median) number of gap-makers was one. The average gap-maker dbh was $36.19 \mathrm{~cm}$, while the average gap-maker basal area per gap was $0.31( \pm 0.27) \mathrm{m}^{2}$. Gap size was highly correlated with the number of gap-makers $(\mathrm{r}=0.81)$ and the total basal area of gap-makers $(\mathrm{r}=$ 0.86). The majority (62\%) of gap-makers were oak species (Figure 16). The origin of each gap in the WVURF was snags (50\%) followed by blow-downs (44\%). Decay created 5\% of gaps and grape vines were responsible for creating gaps $1 \%$ of the time. 


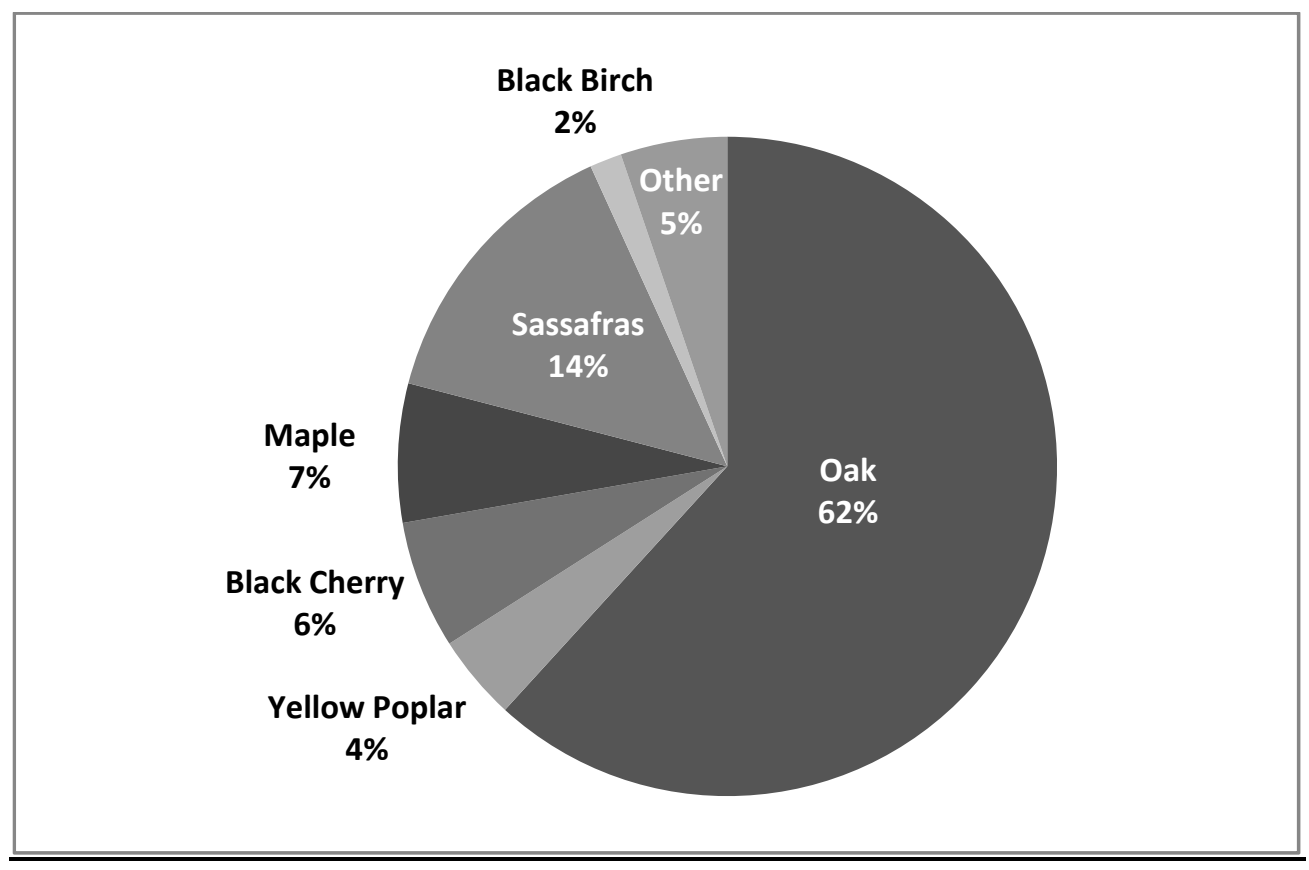

Figure 16: Species composition of gap-makers on the West Virginia University Research Forest. 
CHAPTER 4

\section{DISCUSSION}


Gap characteristic values in undisturbed parts of the WVURF are consistent with values in other eastern hardwoods where single tree disturbances are dominant. Average gap area in the WVURF was $98.59 \mathrm{~m}^{2}$. This value is relatively low in comparison to other forest gap studies (Table 1). Similarly, the average gap fraction was $2.73 \%$, which is on the low end of values reported from other mixed mesophytic forest (Table 1).

Gap disturbances may not only fluctuate through time, but may also vary with the stage of stand development (Dahir and Lorimer 1996). In eastern hardwood forests, canopy gaps are generally smaller in young stands than in old. As stands age and the average tree crown size increases, and the spacing between large individuals is greater than in younger forests. In addition, mortality is increasingly the result of senescence of large and old trees in older stands, which would be expected to create large gaps. Thus, when a canopy tree is lost from an old growth stand, the size of the canopy gap created should be larger than a comparable disturbance during earlier stages of forest development, and loss of these larger trees would result in more pronounced increases in resource levels. (Clebsch and Busing 1989, Dahir and Lorimer 1996, Tyrell and Crow 1994, Busing 1995, Runkle 1998, Beckage et al. 2000, Hix et al. 2003, Hart and Grissino-Mayer 2009).

Because the WVURF is a relatively young forest (70- 80 years old), it is reasonable that both gap size and gap fraction are on average smaller than in older forests. Field observations indicate the WVURF is in or nearing the understory re-initiation stage of forest development of (Oliver and Larson's 1996). During this stage of development the next generation of trees become established by germination of stored seed and subsequent release of new seedling by significant disturbance. Very little recruitment occurs in understory ruination stage except establishment of shade tolerant species. Single tree gaps do not allow recruitment of shade 
intolerant species into upper crown classes. Although canopy gaps in secondary forests are generally smaller in size, they may still act as a mechanism for canopy tree replacement and forest development (Clebsch and Busing 1989,, Wilder et al. 1999, Taylor and Lorimer 2003, Cole and Lorimer 2005).

On the WVURF it is important to keep in mind that large wind events such as tornadoes occur but are relatively rare. High velocity, very localized, and short duration windstorms associated with thunderstorms account for $40-70 \%$ of severe weather events. These winds tend to create gaps during the growing season when trees are full leaf out, soils are near saturation, and foliage is heavy with recent rain. Disturbance agents such as heavy snow, ice storms, lighting, insect, and disease infestations also injure or kill trees and produce gaps (Rentch et al. 2003). It is an interesting note that figure 14 shows the increase in mortality in the years of 1987- 1997 which directly correlated to years of heavy gypsy moth infestation (Muzika et al. 2000). It is speculated because of the immense amounts of snags and direct correlation to age of gaps, gypsy moth was the agent of death for a majority of the trees in the WVURF.

Our results indicated that mean gap size did not vary by aspect or slope position. However, both gap size and expanded gap size were significantly larger in cove hardwoods than in the mesic oak and xeric oak forest types. Gap fraction was also greatest in cove hardwoods. This suggests that some characteristics of the cove hardwood forest type contributed to relatively large canopy gaps and an overall gappier structure.

Because cove hardwoods were dominated by yellow poplar, and fifty percent of yellow poplar had been blown over, I speculate that cove hardwoods have larger gap areas due to larger trees in looser soils that would be more prone to tipping and windthrow. In addition, yellow 
poplar has the potential to be is a less healthy tree (lower site index) at $70-80$ years old than northern red oak. It is believed that yellow polar has a lower site index on the WVURF due to the fact that a majority of the sites that contain yellow poplar are not suited for optimum growth of yellow polar. The tree species is growing off-site and most likely won't reach its maximum age. Therefore, yellow polar is a less healthy tree at $70-80$ years old than northern red oak, and is reaching physiological maturity. Because of the species differences, gap difference will occur, and in this case larger and more frequent gaps in the areas that contain yellow poplar.

Plant community composition may be dependent upon both the frequency of gap creation and the mode of gap phase regeneration (Schnitzer et al. 2000). Over time there is a fundamental compatibility between a species presence and the prevailing disturbance regime. Plant species are found where their life history strategies are compatible with the existing disturbance regime (Rentch et al. 2003). However, without long term observations it is difficult to assess the role of treefall gaps over time (Goldblum 1997). Repeating sampling methods over time or revisiting the 60 gaps found in this study could provide insight into the role of gaps as the WVURF matures.

Treefall gaps may be hot spots of recruitment, seed production, and seed dispersal that serve to maintain the presence of a species in the understory (Goldblum 1997). All species require a minimum gap size to regenerate. Shade intolerant species usually require openings of at least $400 \mathrm{~m}^{2}$ for successful regeneration, while oak regeneration is usually more abundant in multiple tree gaps (Runkle 1982, Clinton et al. 1994, Weiskittel and Hix 2002). The environmental heterogeneity provided by multiple canopy opening sizes could promote a high density of tree seedlings and saplings, and the regeneration of highly desirable and relatively shade intolerant species such as oak, which require large openings (Holladay et al. 2005). An 
estimated $2.5 \%$ of the land area was in gaps $>400 \mathrm{~m}^{2}$, while $60 \%$ of the land was in multiple tree gaps. This observed gap size distribution seems adequate to allow both shade intolerant species and mid tolerant oaks to persist in this forest.

Gaps contained all three classes of tolerance levels. Webster and Lorimer (2004) showed intermediate shade tolerant species require gaps of at least $100 \mathrm{~m}^{2}$, and prefer gaps $>250 \mathrm{~m}^{2}$. Looking at table 3, we see that cove and mid slopes support the gap sizes needed to support recruitment of oaks. This concept of minimum gap size is confirmed when looking at table 7 . Oak IVs show a significant difference between coves/ mid slopes and ridges. The gaps on ridges in this stage of development just aren't big enough for recruitment of oak species.

Red maple occurred across a broad topographic gradient, from mesic sites to xeric sites, and on all aspects and slope positions. The understories of many mesic and dry mesic mature oak forests are presently becoming dominated by later successional species and contain only a small oak component (Gould et al. 2005). Effective fire suppression efforts in the eastern United States are thought to have allowed red maple to expand into upland sites where it had previously been excluded by frequent fires. In the absence of fire, red maple has the capacity to establish and survive in a wide range of habitats, from moist valleys to dry ridge tops. This ecological amplitude allows red maple to regenerate in stands where conditions previously favored other species (Gould et al. 2005). Maple has been noted to be expanding across the landscape; however, it was not the dominant species regenerating in gaps on the WVURF. Even though red maple was not the leading species when data was gathered, the maples will likely be the long term survivors in those gaps unless oak are released by a subsequent disturbance. 


\section{Management Implications Related to this Study}

The study of "natural" (no human influence) forest disturbance is important not only because it determines forest structure, but also because disturbance may act as an important selective force on certain gap colonizing species. The frequency and magnitude of these natural disturbances are important considerations in shaping management policies of forest land (Lorimer 1980). Yet in many cases natural disturbance regimes, their consequences for forest structure, and their variability over the landscape mosaic are poorly understood.

Silviculture often focuses on allocating the available growing space in a forest to the highest quality individuals of preferred species. Most legitimate applications of silviculture focus on meeting management objectives involving regeneration of desired species which, in turn, requires creating conditions that favor those species. An alternative approach is for foresters to use modified silvicultural techniques that mimic natural patterns of disturbances, forest structure, and stand development (Kimball et al. 1995). Forest management policy on many public lands in North America and Europe has undergone a radical shift in recent years from an emphasis on sustainable timber yields on economic rotations to emphasis on overall ecosystem sustainability and the natural disturbance paradigm (Choi et al. 2001). Forest managers need additional information on stand development so that harvest prescriptions can be adjusted to meet long term management objectives. Natural gap dynamics can guide forest

management to regenerate desired species. Follow up study of the 60 gaps found in the WVURF would disclose the dynamics over time.

Understanding the disturbance dynamics, especially the canopy gap dynamics of second growth forests is important in the development of ecosystem management policies (Keller and 
Hix 1999). The framework advanced by this study could aid land managers in implementing informed management policies and practices that more closely resemble the natural disturbances that are occurring in undisturbed portions of the WVURF. 
CHAPTER 5

BIBLIOGRAPHY 
Almquist, B.E., Jack, S.B., and Messina, M.G. 2000. Variation of the treefall gap regime in a bottomland hardwood forest: relationships with micro-topography. Forest Ecology and Management. 157: 155-163.

Anderson, K.L., and Leopold, D.J. 2002. The role of canopy gaps in maintaining vascular plant diversity at a forested wetland in New York State. Journal of the Torrey Botanical Society. 129(3): 238-250.

Barden, L.S. 1980. Tree replacement in a cove hardwood forest of the Southern Appalachians. Oikos. 35: 16-19.

Barden, L.S. 1981. Forest development in canopy gaps of a diverse hardwood forest in the Southern Appalachian Mountains. Oikos. 37: 205- 209.

Barden, L.S. 1983. Size, age, and growth rate of trees in canopy gaps of a cove hardwood forest in the Southern Appalachians. Castanea. 48 (1): 19-23.

Battles, J.J., Fahey, T.J., and Harney, E.M.B. 1995. Spatial patterning in the canopy gap regime of a subalpine Abies-Picea forest in the northeastern United States. Journal of Vegetation Science. 6 (6): 807-814.

Battles, J.J., Dushoff, J.G., and Fahey, T.J. 1996. Line intersect sampling of forest canopy gaps. Forest Science. 42 (2): 131- 138.

Battles, J.J., and Fahey, T.J. 2000. Gap dynamics following forest decline: A case study of red spruce forests. Ecological Applications. 10 (3): 760-774.

Beckage, B., Clark, J. S., Clinton, B.D., and Haines, B. L. 2000. A long-term study of tree seedling recruitment in Southern Appalachian forest: the effects of canopy gaps and scrub understories. Canadian Journal for Forest Research. 30: 1617-1631.

Bormann, F.H., and Likens, G.E. 1979. Catastrophic disturbance and the steady state in northern hardwood forests. American Scientist. 67: 660-669.

Busing, R.T. 1995. Disturbance and the population dynamics of Liriodendron tulipifera: simulations with a spatial model of forest succession. Ecology. 83 (1): 45-53.

Busing, R.T. 2005. Tree mortality, canopy turnover, and woody detritus in old cove forests of the Southern Appalachians. Ecology. 86 (1): 73-84.

Canham, C. D. 1985. Suppression and release during canopy recruitment in Acer saccharum. Bulletin of the Torrey Botanical Club. 112 (2): 134-145.

Canham, C. D., Denslow, J. S., Platt, W. J., Runkle, J. R., Spies, T. A., and White, P. S. 1990. Light regimes beneath closed canopies and tree-fall gaps in temperate and tropical forests. Canadian Journal for Forest Research. 20: 620- 631. 
Carvell, K.L. 1973. Stand composition: Effects of the past on the present. West Virginia Forestry Notes. 1: 3-5.

Clebsch, E. C., and Busing, R.T. 1989. Secondary succession, gap dynamics, and community structure in a Southern Appalachian cove forest. Ecology. 70 (3): 728-735.

Choi, J., Lorimer, C.G., Vanderwerker, J., Cole, W.G., and Martin, G.L. 2001. A crown model for simulating long-term stand and gap dynamics in northern hardwood forests. Forest Ecology and Management. 152: 235- 258.

Clinton, B.D., Boring, L.R., and Swank, W.T. 1994. Regeneration patterns in canopy gaps of mixed- oak forests of the Southern Appalachians: Influences of topographic position and evergreen understory. American Midland Naturalist. 132 (2): 308- 319.

Clinton, B.D., and Baker, C.R. 2000. Catastrophic windthrow in the Southern Appalachians: Characteristics of pits and mounds and initial vegetation responses. Forest Ecology and Management. 126: 51-60.

Clinton, B.D. 2003. Light, temperature, and soil moisture responses to elevation, evergreen understory and small canopy gaps in the southern Appalachians. Forest Ecology and Management. 186: 243- 255.

Cole, W.G. and Lorimer, C.G. 2005. Probabilities of small-gap capture by sugar maple saplings based on height and crown growth data from felled trees. Canadian Journal of Forest Research. 35: 643-655.

Collins, B.S., and Pickett, S. T. A. 1982. Demographic responses of herb layer species to experimental canopy gaps in a northern hardwood forest. Ecology. 76 (2): 437- 450 .

Core, E. L. M. 1974. Monongalia Story, Prelude 1, A Bicentennial History. McClain Printing Co., Parsons, West Virginia.

Crow, T.R. 1988. Reproductive mode and mechanisms for self- replacement of northern red oak (Quercus rubra) - a review. Forest Science. 34 (1): 19- 40.

Cottam, G., and J. T.Curtis. 1956. The use of distance measures in phytosociological sampling. Ecology. 37 (3): 451-460.

Dahir, S. E., and Lorimer, C. G. 1996. Variation in canopy gap formation among developmental stages of northern hardwood stands. Canadian Journal for Forest Research. 26: 1875- 1892.

Dedek, P. B. 1989. The Eliza Iron Furnace: Its operation and History. Brochure sponsored by Southwestern Pennsylvania Heritage Preservation Commission. 
Deike, G. III. 1978. Logging on the South Cheat, the history of the Snowshoe Lands. Trebco Publications. Youngstown, Ohio.

DiGregorio, L. M., Kransy, M, E., and Fahey, T. J. 1999. Radial growth trends of sugar maple (Acer saccharum) in an Alleghany northern hardwood forest affected by beech bark disease. Journal of the Torrey Botanical Society. 126 (3): 245- 254.

Dowdy, S., Wearden, S., and Chilko, D. 2004. Statistics for Research, third edition. John Wiley \& Sons, Inc., Hoboken, New Jersey.

Fekedulegn, D., Colbert, J. J., Rentch, J. S., and Gottschalk, K. W. 2004. Aspect induced differences in vegetation, soil, and microclimate characteristics of an Appalachian watershed. Southern Appalachian Biological Society. 69 (2): 92- 108.

Forrester, J.A., and Runkle, J.R. 2000. Mortality and replacement patterns of an old-growth Acer-Fagus woods in the Holden Arboretum, Northeastern Ohio. American Midland Naturalist. 144 (2): 227-242.

Franklin, J.F., Shugart, H.H., and Harmon, M.E. 1987. Tree death as an ecological process. BioScience. 37 (8): 550- 556.

Fraver, S., and White, A.S. 2005. Disturbance dynamics of old growth Picea rubens forests of northern Maine. Journal of Vegetation Science. 16: 597- 610.

Frelich, L.E., and Lorimer, C.G. 1991. A simulation of landscape-level stand dynamics in the northern hardwood region. Ecology. 79: 223-233.

Frey, B. R., Ashton, M. S., McKenna, J. J., Ellum, D., Finkral, A. 2007. Topographic and temporal patterns in tree seedlings establishment, growth, and survival among masting species of Southern New England mixed- deciduous forests. Forest Ecology and Management. 245: 54- 63.

Gould, P.J., Steiner, K.C., Finley, J.C., and McDill, M.E. 2005. Developmental pathways following the harvest of oak-dominated stands. Forest Science. 51 (1): 76-90.

Goldblum, D. 1997. The effects of treefall gaps on understory vegetation in New York State. Journal of Vegetation Science. 8 (1): 125-132.

Gray, A. N., Spies, T. A., and Easter, M. J. 2002. Microclimate and soil moisture response to gap formation in costal Douglas-fir forests. Canadian Journal for Forest Research. 32: 332- 343.

Greenberg, C. H., and McNab, J. W. 1998. Forest disturbance in hurricane- related downbursts in the Appalachian mountain of North Carolina. Forest Ecology and Management. 104: 179- 191. 
Harr, M. 1992. The C.C.C. Camps in West Virginia, A record of the Civilian Conservation Corps in the mountain state. Published by Milton Harr. Charleston West Virginia.

Hart, J. L., and Grissino-Mayer, H. D. 2009. Gap- scale disturbance processes in secondary hardwood stands on the Cumberland Plateau, Tennessee, USA. Plant Ecology. 201: 131146.

Hix, D.M., Helfrich, K.K., Van Sambeek, J.W., Dawson, J.O., Ponder, F., Jr., Loewenstein, E.F., and Fralish, J.S., 2003. Gap characteristics of southeastern Ohio second-growth forests. Proceedings, 13th Central Hardwood Forest conference; 2002 April 1-3; Urbana, IL. Gen. Tech. Rep. NC-234. St. Paul, MN: U.S.Department of Agriculture, Forest Service, North Central Research Station. 565 p. [Peer-reviewed paper from oral presentation].

Holladay, C.A., Kwit, C., and Collins, B. 2005. Woody regeneration in and around aging southern bottomland hardwood forest gaps: Effects of herbivory and gap size. Forest Ecology and Management. 223: 218-225

Keller, J.A., and Hix, D.M. 1999. Canopy gap fraction and origin in second- growth forests of Washington County, Ohio. Southern Appalachian Botanical Society. 64 (3): 252- 258.

Kimball, A.J., Witham, J.W., Rudnicky, J.L., White, Alan S., and Malcolm, J.L. Jr. 1995. Harvest-created and natural canopy gaps in an oak-pine forest in Maine. Bulletin of the Torrey Botanical Club. 122: (2): 115-123.

Kubo, T., Iwasa, Y., and Furumoto, N. 1996. Forest spatial dynamics with gap expansion: Total gap area and gap size distribution. Journal Theoretical Biology. 180: 229-246.

Lorimer, C.G. 1980. Age structure and disturbance history of a Southern Appalachian virgin forest. Ecology. 61:5: 1169-1184.

Lorimer, G.G., and White, A.S. 2003. Scale and frequency of natural disturbances in the northeastern US: Implications for early successional forests habitats and regional age distributions. Forest Ecology and Management. 185: 41- 64.

McClure, J.W., and Lee, T.D. 1992. Small- Scale disturbance in a northern hardwood forest: Effects on tree species abundance and distribution. Canadian Journal for Forest Research. 23: 1347- 1360.

McClure, J.W., Lee, T.D., Leak, W.B. 2000. Gap capture in northern hardwoods: Patterns of establishment and height growth in four species. Forest Ecology and Management. 127: 181-189.

Moreland, J. R. 1940. The early Cheat Mountain iron works. Morgantown WV. Published by Monongalia Historical Society. 
Muzika, R. M., Liebhold, A.M., and Twery, M.J. 2000. Dynamics of twolined chestnut borer Agrilus bilineatus as influenced by defoliation and selection thinning. Agricultural and Forest Entomology. 2: 283- 289.

Ogden, J., Fordham, R. A., Pilkington, S., and Serra, R. G. 1991. Forest gap formation and closure along an altitudinal gradient in Tongariro National Park, New Zealand. Journal of Vegetation Science. 2 (2): 165-172.

Oliver, C.D. 1980. Forest development in North America following major disturbances. Forest Ecology and Management. 3: 153-168.

Oliver, D.D., and Larson, B.C. 1996. Forest Stand Dynamics. Update edition. John Wiley and Sons, New York.

Orwig, D.A., and Abrams, M. D. 1995. Dendroecological and ecophysical analysis of gap environments in mixed- oak. Functional Ecology. 9 (6): 799- 806.

Paskoff, P. F. 1989. The iron and steel industry in the nineteenth century: Encyclopedia of American business history and biography. Charcoal Fuel pg 84-86. New York: Facts on File.

Phillips, D.L., and Shure, D.J. 1990. Patch- size effects on early succession in Southern Appalachian forests. Ecology. 71 (1): 204- 212.

Rankin, W.T., and Tramer, E.J. 2002. The gap dynamics of canopy trees of a Tsuga canadensis forest community. Northeastern Naturalist. 9 (4): 391-406.

Rantis, P.A., and Johnson, J.E. 2002. Understory development in canopy gaps of pine and pine-hardwood forests of the upper coastal plain of Virginia. Plant Ecology. 159: 103115.

Rebertus, A.J., and Meier, A.J. 2001. Blowdown dynamics in oak- hickory forests of the Missouri Ozarks. Journal of the Torrey Botanical Society. 128 (4): 362-369.

Rentch, J.S., Fekedulegn, D.B., and Miller, G.W. 2002. Climate, canopy disturbance, and radial growth averaging in a second-growth mixed-oak forest in West Virginia, U.S.A. Canadian Journal of Forest Research. 32 (6): 915-927.

Rentch, J.S., Fajvan, M.A., and Hicks, R.R. Jr. 2003. Spatial and temporal disturbance characteristics of oak-dominated old-growth stands in the central hardwood forest region. Forest Science. 49 (5): 778-789.

Rodd, J. S. 1994. A guide to Coopers Rock State Forest. Published by Barn Echo Press. Moatsville, WV. USA. 
Romme, W.H. and Martin, W.H. 1982. Natural disturbance by tree - falls in old-growth mixed mesophytic forest: Lilley Cornett Woods, Kentucky. In Central Hardwood Forest Conference IV Proceedings. Edited by R.N. Muller. pp. 367-383. University of Kentucky, Lexington.

Rost, T.L., Barbour, M.G., Stocking, C.R., and Murphy, T.M. 2006. Plant Botany, second edition. Thomson/ Brooks/ Cole Publications. Printed in Canada. Pp. 80-81.

Runkle, J.R. 1981. Gap regeneration in some old-growth forest of the eastern United States. Ecology. 62 (4): 1041-1051.

Runkle, J.R. 1982. Patterns of disturbance on some old-growth mesic forests of eastern North America. Ecology. 63 (5): 1533-1546.

Runkle, J.R. 1984. Development of woody vegetation in treefall gaps in a beech-sugar maple forest. Holarctic Ecology. 7: 157-164.

Runkle, J.R. 1985. Comparison of methods for determining fraction of land area in treefall gaps. Forest Science. 31 (1): 15-19.

Runkle, J.R. 1989. Synchrony of regeneration, gaps, and latitudinal differences in tree species diversity. Ecology. 70 (3): 546-547.

Runkle, J.R. 1990. Gap dynamics in an Ohio Acer-Fagus forest and speculations on the geography of disturbance. Canadian Journal for Forest Research. 20: 632- 641.

Runkle, J.R. 1992. Guidelines and sample protocol for sampling forest gaps. Gen. Tech. Rep. PNW-GTR-283. Portland, OR: U.S. Department of Agriculture, Forest Service, Pacific Northwest Research Station : 1-44.

Runkle, J.R. 1998. Changes in Southern Appalachian canopy gaps sampled thrice. Ecology. 79: $1768-1780$.

Runkle, J.R. 2000. Canopy tree turnover in old-growth mesic forests of Eastern North America. Ecology. 81(2): 554-567.

Runkle, J.R., Yetter, T.C. 1987. Treefalls revisited: Gap dynamics in the southern Appalachian. Ecology. 68 (2): 417-424.

Schnitzer, S.A., Dalling, J.W., and Carson, W.P. 2000. The impact of lianas on tree regeneration in tropical forest canopy gaps: Evidence for an alternative pathway of gapphase regeneration. Ecology. 88 (4): 655-666.

Stringer, J.W., Kimmerer, T.W., Overstreet, J.C., and Dunn, J.P. 1989. Oak mortality in Eastern Kentucky. Society Journal American Foresters. 13: 86- 91. 
Tajchman, S.J., and Wiant, H.V. Jr. 1983. Topography and biomass characteristics of a forested catchment in the Northern Appalachians. Forest Ecology and Management. 5: 55- 69.

Taylor, S.O., and Lorimer, C.G. 2003. Loss of oak dominance in dry- mesic deciduous forests predicted by gap capture methods. Plant Ecology. 167: 71- 88.

Tyrell, L.E., and T.R. Crow. 1994. Structural characteristics of old-growth hemlock-hardwood forests in relation to age. Ecology. 75:370-386.

U.S. Department of Agriculture (USDA). 1959. Soil Survey of Preston County, West Virginia. USDA Soil Conservation Service, Washington, D.C.

Valverde, T., and Silvertown, J. 1997. Canopy closure rates and forest structure. Ecology. 78 (5): 1555- 1562.

Webster, C.R., and Lorimer, C.G. 2005. Minimum opening sizes for canopy recruitment of midtolerant tree species: A retrospective approach. Ecological Applications. 15 (4): $1245-1262$.

Weiskittel, A.R., and Hix, D.M. 2002. Canopy gap characteristics of an oak- beech maple old- growth forest in northeastern Ohio. Ohio Journal of Science. 103 (4): 111-115.

Whitmore, T.C. 1989. Canopy gaps and the two major groups of forest trees. Ecology. 70 (3): 536- 538.

Wilder, C.M., Holtzclaw, F.W. Jr., Clebsch, E.E.C. 1999. Succession, sapling density and growth in canopy gaps along a topographic gradient in a second growth East Tennessee forest. American Midland Naturalist. 142: 201- 212.

Wiley, S. T. 1883. History of Monongalia County. Preston Publishing Co.

Williams, M. 1989. Americans and their forests, A historical geography. Cambridge Univ. Press. Pgs. 106-107, 342-344.

Woods, K.D. 2004. Intermediate disturbance in a late- successional hemlock- northern hardwood forest. Ecology. 92: 464- 476.

Yetter, T.C., and Runkle, J.R. 1986. Height growth rates of canopy tree species in Southern Appalachian gaps. Castanea. 51 (3): 157-167.

Young, T.P., and Hubbell, S.P. 1991. Crown asymmetry, treefalls, and repeat disturbance of broad- leaved forest gaps. Ecology. 72 (4): 1464- 1471. 


\section{CURRICULUM VITAE}

\section{EDUCATION}

Clarion University of Pennsylvania, Clarion, PA; BS Biology, Concentration in Ecology and Evolutionary Science (GPA - 3.3) Graduated May 2007

-Summer Field Study Classes, Graduate Level: Forest Ecology, Aquatic Ecology

West Virginia University, Morgantown, WV; MS Forestry (GPA - 3.90) Degree expected August 2009 -Research Assistantship

\section{CERTIFICATES, AWARDS, CLUBS, AND CONFERENCES}

- National Deans List

- Ecology Scholarship from the Pymatuning Lab of Ecology, Univ. of Pittsburgh, Summer 2005

- Society of American Foresters (WVU and National chapters)

- WVU Chapter of Xi Sigma Pi, National Forestry Honor Society

- Davis College of Agriculture, Forestry \& Consumer Science, 13 $3^{\text {th }}$ Annual Student Research Conference- Paper Presentation

- Paper Presentation accepted to the North American Forest Ecology Workshop, Utah State University, Logan, Utah- June 22-25, 2009

\section{RELEVANT COURSE WORK}

UNDERGRADUATE

PLANT ECOLOGY

FRESHWATER ECOLOGY

CELL BIOLOGY

GENETICS

ECOLOGICAL APPLICATIONS

COMM \& ECOSYS DYNAMICS

GENERAL BOTANY

ORGANIC CHEM I \& II

BIOCHEM I

GENERAL PHYSICS I \& II
GRADUATE

STATISICS I \& II

SPATIAL ANALYST, RESOURCE MNGMNT (GIS) APPLIED GIS TO NATURAL SCIENCE ADVANCED FOREST ECOLOGY FOREST STAND DYNAMICS

SILVICULTURE

LAB INSTRUCTOR FOR DENDROLOGY

\section{MASTERS RESEARCH}

Treefall Gap Characteristics within an Appalachian Hardwood Forest in West Virginia: Influences of Topographic Position and Forest Type

\section{SKILLS}

$\checkmark$ Microsoft Excel

$\checkmark$ Microsoft Word

$\checkmark$ Microsoft PowerPoint $\checkmark$ Tree Identification

$\checkmark$ ARCMAP (Geographic Information System)

$\checkmark$ SAS 